University of Rhode Island

DigitalCommons@URI

2000

\title{
Paleoenvironments of Early Theropods, Chinle Formation (Late Triassic), Petrified Forest National Park, Arizona
}

François Therrien

University of Rhode Island

David E. Fastovsky

University of Rhode Island

Follow this and additional works at: https://digitalcommons.uri.edu/geo_facpubs

Terms of Use

All rights reserved under copyright.

\section{Citation/Publisher Attribution}

Therrien, F., \& Fastovsky, D. E. (2000). Paleoenvironments of Early Theropods, Chinle Formation (Late

Triassic), Petrified Forest National Park, Arizona. PALAIOS, 15(3), 194-211. doi: 10.1669/

0883-1351(2000)015<0194:POETCF>2.0.C0;2

Available at: https://doi.org/10.1669/0883-1351(2000)015<0194:POETCF>2.0.C0;2

This Article is brought to you for free and open access by the Geosciences at DigitalCommons@URI. It has been accepted for inclusion in Geosciences Faculty Publications by an authorized administrator of DigitalCommons@URI.For more information, please contact digitalcommons-group@uri.edu. 


\title{
Paleoenvironments of Early Theropods, Chinle Formation (Late Triassic), Petrified Forest National Park, Arizona
}

\author{
FRANÇOIS THERRIEN* and DAVID E. FASTOVSKY \\ Department of Geosciences, University of Rhodel sland, Kingston, RI 02881
}

\section{PALAIOS, 2000, V. 15, p. 194-211}

Thre localities in the Chinle Formation (Late Triassic), Petrified Forest National Park (PEFO), Arizona, provideinsights into the paleoenvironments frequented by primitive North American theropods. At the Dinosaur Wash locality, an undetermined theropod is preserved in paleosols that indicate a transition from wet to dry conditions on thefloodplain. Coelophysis bauri remains from the Dinosaur Hill locality are preserved in a filled channel scour. The paleosols at this locality contain carbonate nodules intimately associated with Feand $\mathrm{Mn}$ oxides, indicative of al ternating alkaline/ acidic conditions around roots in response to a semi-arid di imate with strong seasonal precipitation. At the Dinosaur Hollow locality, Chindesaurus bryansmalli is preserved in a setting similar to thoseencountered at Dinosaur Hill. The paleosols exhibit vertic features, such as pseudoanticlines, and areindicativeof water-deficit periods during theyear.

The most complete theropod remains at PEFO are pre dominantly preserved in distinctive bluecolored paleosol horizons showing depletion in iron and alumi num, and exhibiting features such as localized Fe concentrations and mottling. These are interpreted as A-horizons of redoximorphic paleosols developed in wet areas of the floodplain wherethe degree of water saturation fluctuated.

Preservational conditions of PEFO theropod localities indicate they are timeaveraged attritional mortality assemblages representative of contemporaneous organisms. Comparison of these localities to the well-known Ghost Ranch, New Mexico, Coel ophysis quarry reinforces theidea that the quarry represents unique preservational conditions.

\section{INTRODUCTION}

Strata bearing Coelophysis and other primitive small theropod taxa are known from the Petrified Forest National Park (PEFO) of northeastern Arizona (Padian, 1986; see Parrish, 1993; Long, 1985; Hunt et al., 1995, 1996, 1998; for complete listing), but few intensive taphonomic or pal eoenvironmental studies have been conducted (e.g. Murry and Long, 1989). Indeed, some ambiguity exists about the pal eoenvironments of these early dinosaurs. For example, Long et al. (1988) envisioned an extremely wet environment, while Dubiel et al. (1991) reconstructed a strongly continental climate with intense seasonality characterized by wet and dry intervals. The discovery of

* Current address: Department of Cell Biology and Anatomy, J ohns Hopkins University, School of Medicine, Baltimore, MD 21205. theropod specimens in PEFO (Late Triassic Chinle Formation) allows insights into the paleoenvironments in which theropods lived, as well as provides a counterpoint for behavioral inferences based upon the well-known Ghost Ranch, New Mexico, Coelophysis quarry.

Three theropod localities in PE F O wereselected (Fig. 1), on the basis of the degree of completeness and articulation of the skeletons discovered, for comparison with the Coe lophysi s quarry at Ghost Ranch, N ew Mexico: (1) Dinosaur Wash, situated in the southern part of the Park in the Tepees-Blue Mesa vicinity; (2) Dinosaur Hill, situated in the northern part of PEFO to the southwest of Lacey Point; and (3) Dinosaur Hollow, also in the northern part of PEFO, but situated in proximity of Chinde Point. Because the localities preserve semi- to fully-articulated specimens, it is reasonable to assume that they represent environments in which theropods lived. Whenever possible, localities bearing identified theropod taxa were selected over those bearing undetermined theropods. The remains of Coel ophysis bauri have been discovered at Dinosaur Hill (Padian, 1986), Chindesaurus bryansmalli was found at Dinosaur Hollow (Murry and Long, 1989), and an undetermined theropod was discovered at Dinosaur Wash by the crew of the "Dawn of the Dinosaurs" project, led by A.P. Hunt, during the summer of 1998.

Strikingly, the bones are concentrated primarily in blue-colored horizons in all of these localities. The exclusive accumulation of bones in blue-colored mudstones is not unknown in the Colorado Plateau sediments; Clark and Fastovsky (1986) reported this type of selective preservation of vertebrate fossils in blue layers in the J urassic Kayenta Formation, although they did not explain the phenomenon. Here we address this issue, as well as the paleoenvironments of the fossil-bearing localities of the Chinle F ormation.

\section{GEOLOGIC SETTING}

The Late Triassic Chinle Formation is a continental, fluvial sequence that was deposited in a vast back-arc basin on the western margin of Pangea (Stewart et al., 1972; Blakey and Gubitosa, 1983; Dubiel, 1989a, 1994). Based on paleomagnetic data, the Chinle basin was situated between $5^{\circ}$ and $15^{\circ}$ in the tropical belt north of the Late Triassic paleoequator (Van der Voo et al., 1976; Witte and Kent, 1989; Bazard and Butler, 1991).

Siliciclastic sediment was derived from two major mountain belts bordering the Chinle basin at the time. Sediments were deposited in the basin during the Late Triassic by rivers flowing south, west, and northwest from the presumed highlands located where the Rocky Mountains later developed, and by rivers flowing north and 


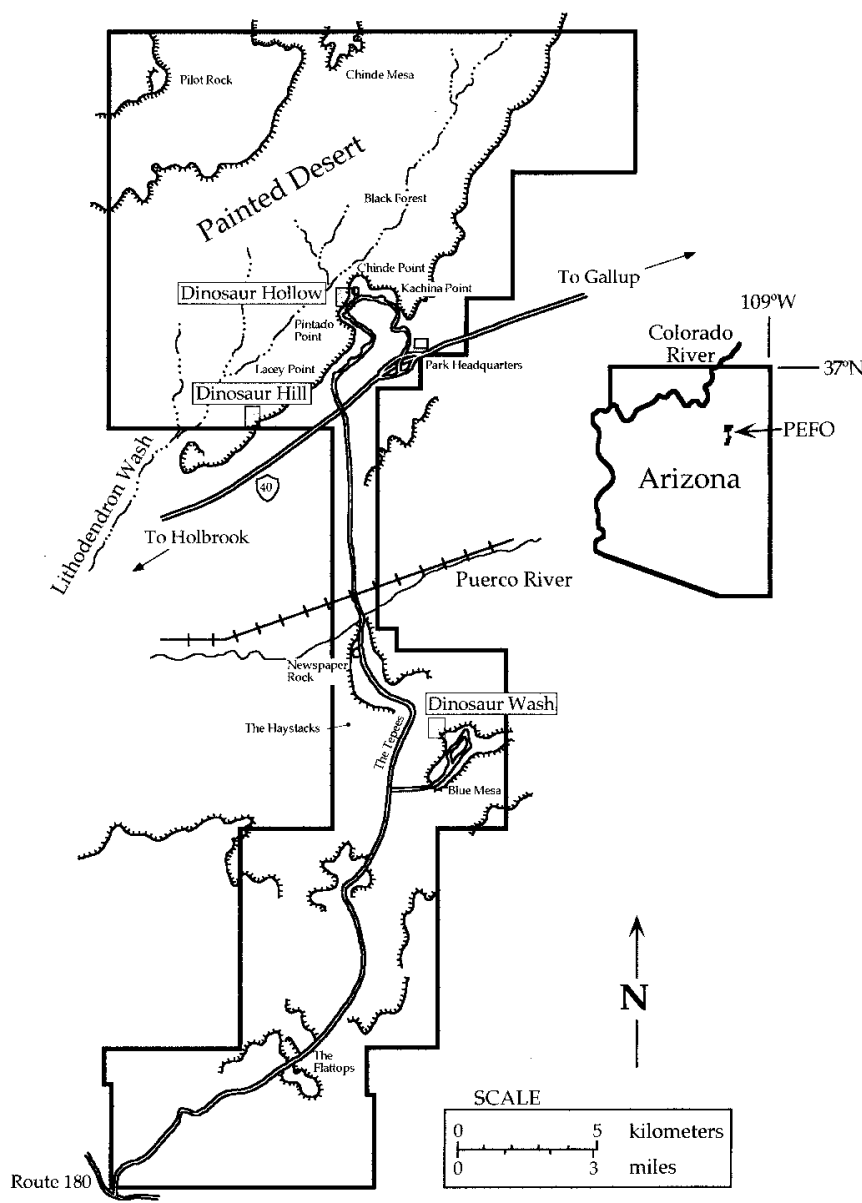

FIGURE 1-Theropod localities studied in Petrified Forest National Park: Dinosaur Wash, Dinosaur Hill, and Dinosaur Hollow.

northwest from the Mogollon Highlands (Stewart et al., 1972; Blakey and Gubitosa, 1983; Dubiel, 1989a, b; Therrien, 1999).

Chinle exposures occur throughout the Colorado Plateau, in Arizona, New Mexico, Colorado, Utah, and southern Nevada. The predominantly siliciclastic unit consists of conglomerate, sandstone, and mudstone lithofacies and has been divided into an array of complexly interfingering members on the basis of gross lithology and color (Stewart et al., 1972; Blakey and Gubitosa, 1983; Dubiel 1989a, b, 1994; Dubiel et al., 1991; also see Lucas, 1993).

Outcrops within PEFO consist of multicolored mudstones and siltstones, sandstone, conglomerate, and limestone beds that vary greatly in thickness and lateral extent. Pedogenically modified mudstones composed of randomly interstratified illite and smectites (Zuber, 1990) are abundant in the Park. These strata are interpreted as deposits within a fluvial system, some of which show evidence of paleosol development.

\section{METHODS}

A detailed composite stratigraphic section of PEFO, diverging in some details from previous efforts (Billingsley, 1985a, b; Murry, 1990; Lucas, 1993; Dubiel et al., 1995; Heckert, 1997), was constructed by measuring 33 colum-

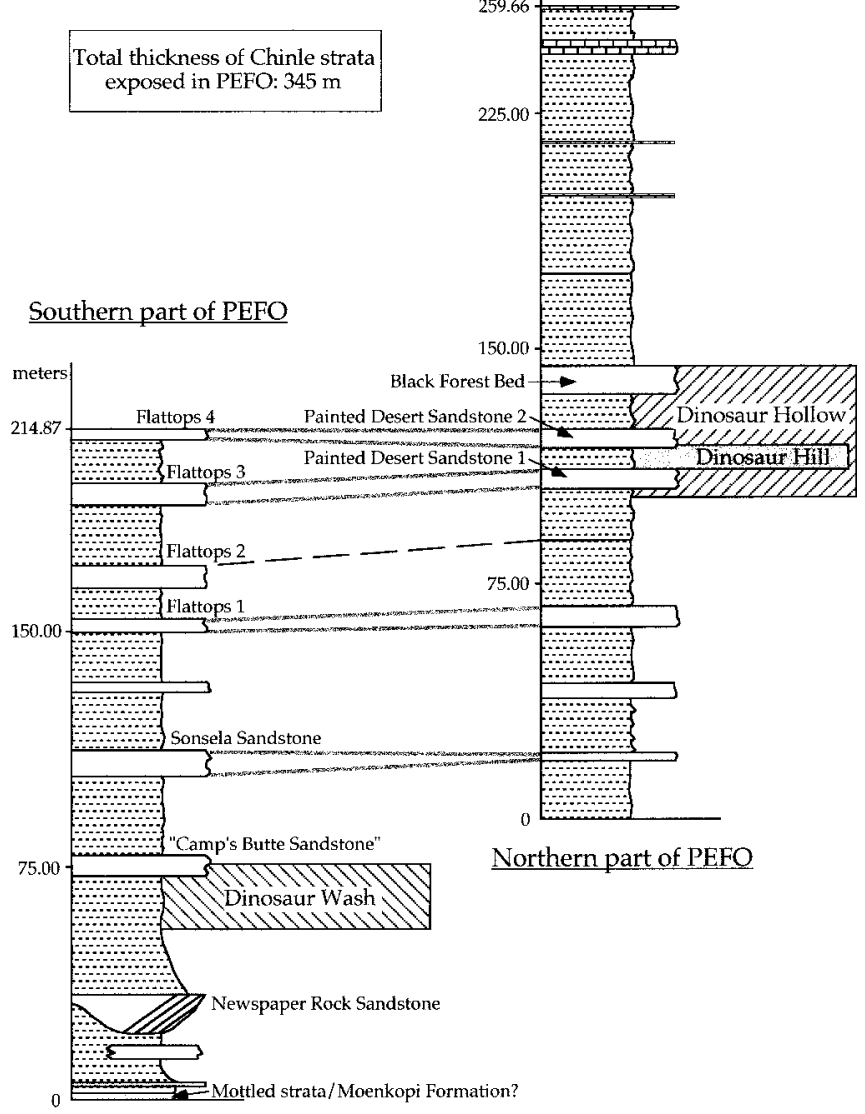

FIGURE 2-Composite stratigraphic section of Petrified Forest National Park constructed from 33 measured sections within and outside the Park. A long covered interval occurs between the north and south ends of PEFO; correlation between the northern and southern ends of the Park was made by tracing the Sonsela Sandstone and the underlying strata in the south up to the closest outcrop to the northern lithologies.

nar sections within and outside the Park (Fig. 2). Each locality was physically correlated to the composite section. Integrating each locality in the stratigraphic context of PEFO allows a robust chronologic and stratigraphic control over the paleoenvironmental and faunal changes reported to occur within the Chinle Formation at PEFO (Therrien et al., 1999; Herrick et al., 1999).

Detailed descriptions of the outcrops exposed at each locality were made and representative samples of each stratigraphic unit were collected. The micromorphol ogy of pal eosols was studied utilizing 58 thin sections. Geochemical analyses for major and trace el ements were made by a Kevex model 700 X-ray fluorescence (XRF) spectrophotometer on 30 samples of different paleosol sequences.

\section{PALEOENVIRONMENTAL RECONSTRUCTION}

The study of paleosols and their micromorphology has much to contribute to the reconstruction of paleoenvironments in which vertebrates remains are found (e.g., Bown and Kraus, 1981a, b; Retallack, 1983; Fastovsky and McSweeney, 1987; McCarthy et al., 1998). Some of the key 
pedogenic features observed in PEFO paleosols, as well as their interpretations, are outlined below.

\section{Gleyed Matrix and Mottles}

Gleyed paleosols having a chroma of 1 on the Munsell Soil Color Chart (Munsell, 1992) are abundant at Dinosaur Wash and at stratigraphically lower levels in PEFO, although they are occasionally observed at Dinosaur Hill and Dinosaur Hollow. Gleyed paleosol sequences are thick and laterally extensive at Dinosaur Wash, commonly reaching $8 \mathrm{~m}$ in thickness, and may be traced laterally for hundreds of meters. At Dinosaur $\mathrm{Hill}$ and Dinosaur $\mathrm{Hol}$ low, the gleyed intervals generally are relatively thin (maximum $3 \mathrm{~m}$ ) and of limited lateral extent.

Mottles in these paleosols consist of localized accumulations or depletions of Fe and Mn. They are found at different stratigraphic levels at Dinosaur Wash and Dinosaur Hollow, but are very common and larger in size at Dinosaur Wash. In the two stratigraphically highest localities of PEFO, the mottling is generally associated with root traces (see below).

\section{Color of Paleosols}

The color of paleosol horizons reflects the concentration of iron and manganese compounds in the matrix. The red coloration of the paleosols present at Dinosaur Hill and Dinosaur Hollow is primarily due to the abundance of iron oxides, mostly hematite, accompanied by a low content of organic matter (McBride, 1974; Bown and Kraus, 1981a). The purple and red colors represent better-drained and oxidizing conditions. The gray, greenish, and bluish colors observed at the PEFO localities are indicators of iron depletion. These colors are usually related to water saturated conditions under which the paleosols formed and suggest impeded drainage and reduced conditions in the Chinle paleosols.

\section{Microstructures and Fabrics}

Peds, natural aggregates of soil matrix, are formed by the shrinking and swelling of clays resulting from alternating dry and wet soil conditions. The majority of the peds present in the PEF O paleosols are subangular blocky (Fig. 3A), although granular and angular blocky peds are observed occasionally at Dinosaur Hill and Dinosaur $\mathrm{Hol}-$ low.

The alignment of clays in the paleosols, creating bire fringence in thin sections, is termed b-fabric (Bullock et al., 1985). Streaked, continuous, and undifferentiated fabrics were observed in paleosols of all the localities. Peds and streaked b-fabric indicate that the horizon was undergoing shrinking and swelling of clays due to repetitive wetting and drying of the pal eosols (Fig. 3B). Undifferentiated fabrics were formed under oxidizing conditions where iron precipitated, and continuous fabrics are interpreted as evidence of weak to no pedogenic modification.

\section{Fe and Mn Oxides}

I ron and manganese accumulations are observed commonly in Chinlepaleosols (Fig. 3C). They occur as coatings around clastic grains, peds, carbonate nodules, and along root traces. At Dinosaur Hill and Dinosaur Hollow, Feand $\mathrm{Mn}$ are observed to form compound features with carbonate nodules (Fig. 3C). F erich coatings also are seen to act as cappings and link cappings on grains (Bullock et al., 1985).

Iron and manganese eluviation and illuviation were, therefore, significant pedogenic processes in the paleosols of each locality. These coatings are formed when ferrousrich water percolated through the ground and encountered oxidizing conditions or higher $\mathrm{pH}$ conditions, leading to the precipitation of oxides.

\section{Clay Accumulations}

Clay accumulation can be observed in the paleosols of each locality in the form of clay coatings and root-trace fillings. Clay coatings are observed most commonly as oriented clay accumulations along root walls or pore linings. Finely laminated clay coatings, interbedded with iron oxides, are exceptionally well-developed in the Dinosaur Hollow paleosols (Fig. 3D) but are also observed at Dinosaur Hill. Intraclasts, peds, and carbonate nodules of the Dinosaur Hill and Dinosaur Hollow paleosols are commonly surrounded by clay coatings.

Clay illuviation was an active pedogenic process in the PEFO paleosols. Precipitation must have been sufficiently higher than evapotranspiration at times to carry clay downward from surficial horizons.

\section{Carbonate Nodules}

Carbonate nodules are one of the most common illuvial pedofeatures observed, but they are absent in the lower part of Dinosaur Wash. The carbonate nodules are rounded to subrounded, range in size from $0.01 \mathrm{~mm}$ to $5 \mathrm{~cm}$, and usually are found in mudstones and siltstones, but occasionally are present in some sandstones. Microscopically, the carbonate nodules are micritic or sparry and often show intergrowth with $\mathrm{Fe}$ and $\mathrm{Mn}$ oxides in the Dinosaur Hill and Dinosaur Hollow paleosols (Fig. 4). In these paleosols, carbonate nodules often are associated closely with root traces and coalesce to form rhizocretions. The rhizocretions are generally $3 \mathrm{~cm}$ in diameter, but rhizocretions up to $15 \mathrm{~cm}$ in diameter are observed at Dinosaur Hill.

Carbonate nodules are known to form in semi-arid climates where limited precipitation results in the incomplete leaching of carbonate from the soil. Local translocation and accumulation of carbonate occurs instead (Goudie, 1983). Rainwater percolating through the soil carries the carbonate in solution, but the water evaporates before reaching the water table; ther efore, the carbonate precipitates at the average depth of rainfall penetration, often termed the wetting front (Goudie, 1973; Reeves, 1976; Blodgett, 1988).

\section{BIOTURBATION}

Root traces and burrows are observed commonly in the paleosols of the four localities studied. Root traces occur as filled root channels or rhizocretions. The filled root traces can contain mud, clastic grains, carbonatenodules, Fe-Mn 

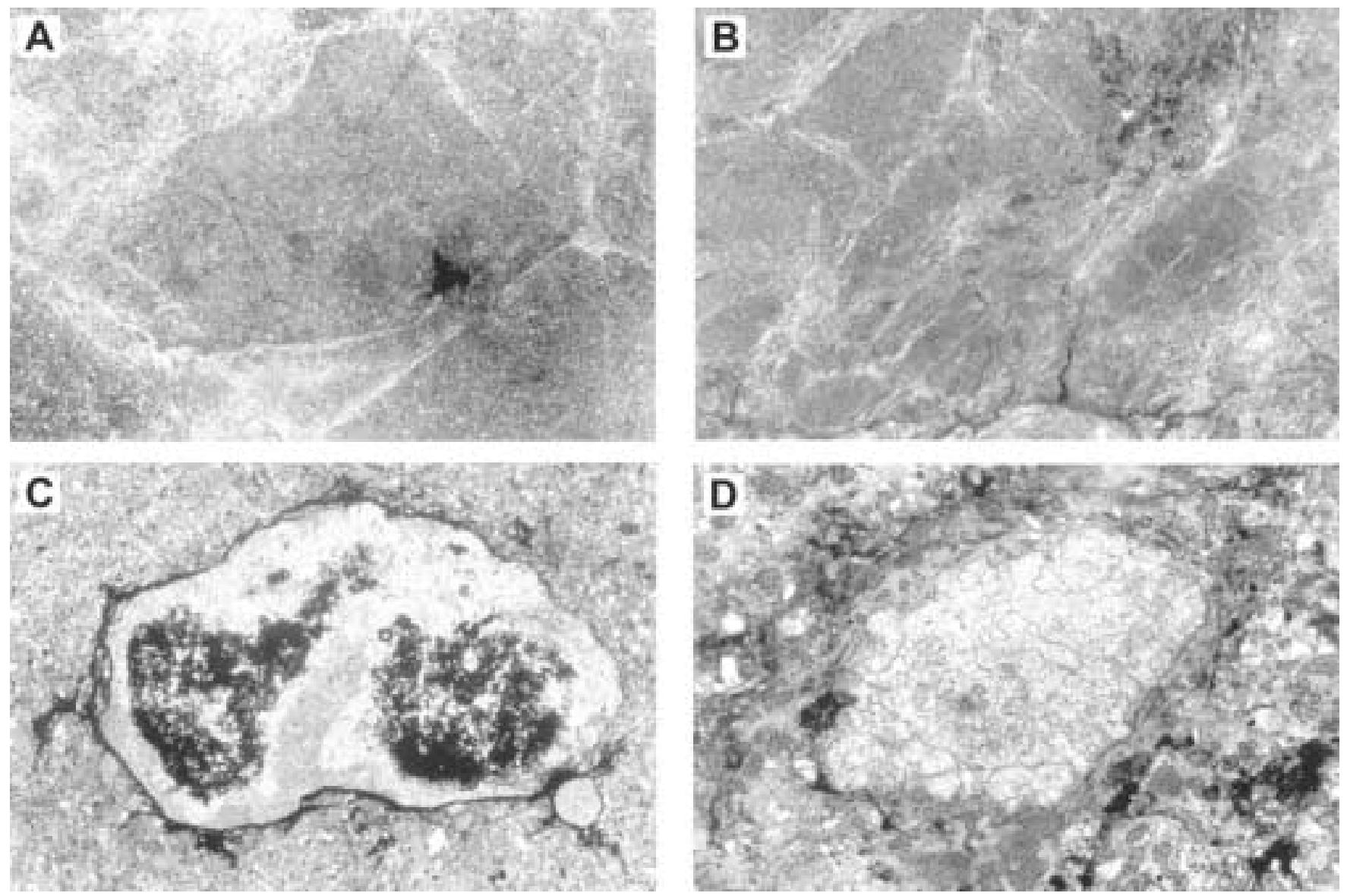

FIGURE 3-Photomicrographs of key pedogenic features observed in Chinle paleosols. (A) Subangular blocky ped surrounded by a high birefringence clay coating. Picture taken under crossed polarizers; field of view is $9 \mathrm{~mm}$ wide. (B) Streaked b-fabric, resulting from the orientation of clay minerals after shrinking and swelling. Picture taken under crossed polarizers; field of view is 19 mm wide. (C) Compound pedofeature consisting of a carbonate nodule with impregnation and coating of manganese and iron oxides. The coating links with a second, smaller carbonate nodule in the lower right corner. Picture taken under crossed polarizers; field of view is $3.3 \mathrm{~mm}$ wide. (D) Finely laminated clay coating on a carbonate nodule. Note the fine laminae of iron oxides incorporated in the clay coating on the SE face of the nodule. Picture taken in plane polarized light; field of view is $1.3 \mathrm{~mm}$ wide.

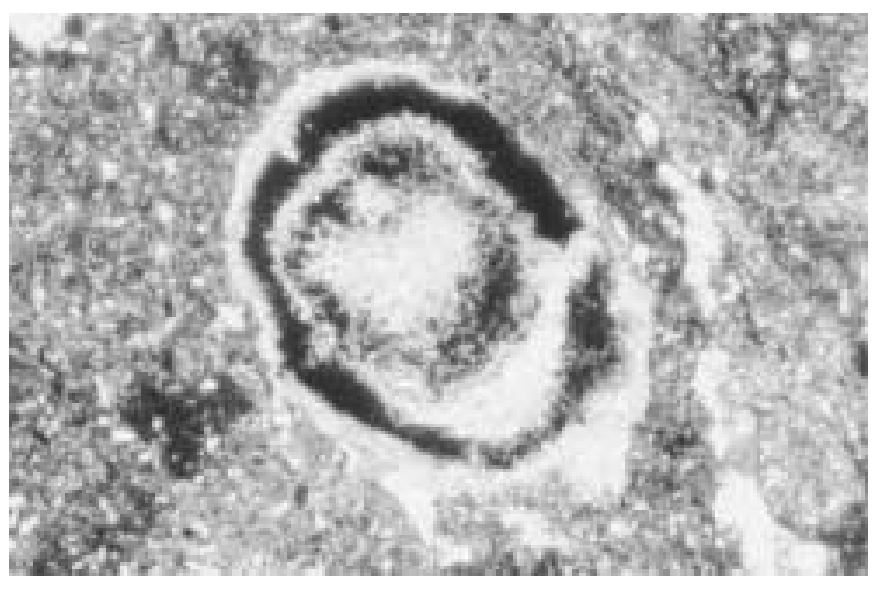

FIGURE 4-Photomicrograph of concentric rings of ferruginous oxides inside a carbonate nodule at Ghost Ranch. Picture taken under crossed-polars; field of view is $1.3 \mathrm{~mm}$ wide. oxides and other debris that fell in from the surface. At the Dinosaur Wash locality, elongate, striated, cylindrical burrows, referred to the ichnogenus Scoyenia, are observed commonly in the non-gleyed horizons. These Scoyenia burrows, inferred to have been made by arthropods, are indicators of moist to saturated substrates (Hasiotis and Dubiel, 1993).

\section{SLICKENSIDES}

Slickensides are common in the pedogenically-modified mudstones and siltstones of the Chinle paleosols, but also are observed occasionally in very muddy fine-grained sandstones. Slickensides can indicate seasonal wetting and drying when found in smectite-rich deposits (e.g., Dudal and Eswaran, 1988; Wilding and Tessier, 1988), but also may occur non-pedogenically in reexhumed paleosols.

\section{HORIZON RECOGNITION}

Periodic deposition of material during a flood event creates one soil on top of another. Pedogenesis can occur across the boundaries between the two soils and compli- 
cate the recognition and interpretation of the various paleosol horizons (termed "cumulative paleosols" and "compound pedogenesis"; see Birkeland, 1974; Retallack, 1983; Kraus and Bown, 1986; F astovsky and MCSweeney, 1991).

Identification of A-horizons is always speculative be cause organic matter commonly is not preserved in oxidizing environments. However, A-horizons were inferred on the basis of intense bioturbation, lack of illuvial features, geochemistry, and relative position in the paleosol profile. Occasionally, horizons associated with a paleosol profile did not show evidence of pedogenesis and exhibited primary sedimentary structures. Such unaltered horizons were considered parent materials (C horizons). Horizons exhibiting evidence of clay illuviation, in the form of clay coatings on grains and along root walls, and streaked bfabric related to porelining were interpreted as Bt horizons. Horizons containing abundant carbonate accumulation, most commonly in the form of nodules, accompanied by other illuvial features were interpreted as Bk horizons. Some horizons exhibited only minor traces of illuviation, with relatively poorly devel oped clay coatings or carbonate accumulation; these were referred to as Bw horizons. Hydromorphic (gleyed) horizons were interpreted as $\mathrm{Bg}$ or $\mathrm{Cg}$ horizons, which were, in turn, distinguished from one another on the basis of soil structure.

\section{COMPARISON OF THEROPOD LOCALITIES}

\section{Dinosaur Wash Locality}

Dinosaur Wash is situated in the southern part of PEFO, near the base of the geomorphologic feature called Blue Mesa (Figs. 1, 2). The facies are relatively flat lying and follow the contour intervals as the local dip is approximately $3^{\circ}-5^{\circ}$ to the east-northeast (Fig. 5). The locality is dominated by pedogenically modified mudstone intervals with capping trough and tabular cross-stratified sandstones and congl omerates.

\section{Fluvial System}

Local scours, inferred to represent paleochannels, dissect mudstones in the Dinosaur Wash region. The paleochannels are filled by mudstones on which paleosols developed following channel abandonment. The degree of maturity of scour-fill paleosols differs from the one of dissected mudstone paleosols, indicating they formed independently (Kraus and Bown, 1986; also see Kraus and Middleton, 1987).

Situated one km to the northwest and approximately 30 $m$ below the stratigraphic level of Dinosaur Wash, a series of inclined heterolithic strata (IHS) dip into a filled channel (Fig. 6). This 9-m-thick IHS unit exhibits climbing-ripple cross-lamination indicating a paleocurrent direction perpendicular to the dip of thestrata; ther efore, thesel HS are interpreted as lateral accretion surfaces left by the migration of a point bar (Allen, 1965; J ackson, 1978; Collinson, 1978; Bridge, 1985). Although the IHS are stratigraphically lower than the Dinosaur Wash locality, nomajor sedimentologic variation is observed in the stratigraphic interval comprised between the two sites. Furthermore, paleosol sequences are similar throughout the interval, indicating that no noticeable paleoenviron- mental changes occurred in the time between the deposition of the IHS and that of Dinosaur Wash. Hence, it is reasonable to say that the fluvial systems responsible for the formation of the IHS and Dinosaur Wash were probably similar.

This fluvial system is generally mudstone-dominated. Nevertheless, the use of mudstone/sandstone ratios preserved in vertical sequences as an indicator of fluvial system can be misleading. Thick overbank deposits commonly are associated with high-sinuosity rivers but thin overbank deposits are not necessarily an indicator of braiding, as some meandering rivers are known to have very little mudstone preserved in their vertical sequences ( ackson, 1978). H owever, this fluvial system is floodplain-dominated; a relatively small proportion of channel deposits are preserved, suggesting that Dinosaur Wash lithologies were mainly the result of suspension-load, high-sinuosity streams.

The trough-to-tabular cross-stratified sandstones and conglomerates situated at the top of the stratigraphic sequence of Dinosaur Wash are interpreted as having been deposited by mi grating sandbars in a low-sinuosity fluvial system.

\section{Paleosols}

Compound pal eosol sequences are present at Dinosaur Wash, and indicate a transition from a wet to a drier paleoenvironment. In the lower part of the locality, gleyed pal eosols with large, diffuse $\mathrm{F}$ eand $\mathrm{Mn}$ concentrations are present. Gleyed matrices and $\mathrm{Fe}$ and $\mathrm{Mn}$ concentrations are associated with poorly drained paleosols and a high, but fluctuating, water table. The gleyed matrix is an indicator of reducing conditions in the paleosol, typically due to a relatively prolonged period of water saturation (25$50 \%$ of the year; Daniels et al., 1971) when iron and manganese are reduced. Fe and $\mathrm{Mn}$ concentrations are formed under alternating reducing and oxidizing conditions in the paleosol, associated with a fluctuating water table (e.g., Vepraskas, 1992). Diffuse Fe and Mn concentrations form in horizons with a longer period of saturation (Crown and Hoffman, 1970). Carbonate nodules are absent from the gleyed paleosol sequence, and illuviated clays are extensive in the upper horizon (Fig. 7A).

By contrast, the upper pal eosols exhibit a bluish (10PB $6 / 2$ ) calcic horizon toward the top of the sequence, in which the bones are thought to be preserved (see below; Fig. 7B). Clay illuviation is not as common in the B-horizons of the upper paleosols, as was observed in the gleyed paleosols. There is no evidence of extensive periods of water saturation. This change in pedogenic features is interpreted as reflecting changes of the soil-forming conditions due to a drier paleoenvironment. Carbonate nodules occur at lower stratigraphic levels in PEFO (see Demko, 1995), but most are found within or close to gleyed horizons; thus, their mode of formation is probably related to a carbonaterich groundwater (Goudie, 1983) and independent of the climatic conditions (Aslan and Autin, 1998).

Permineralized tree stumps are preserved in growth position on top of gleyed paleosols. This observation, in combination with the evidence of bioturbation and casts of giant horsetails (Neocalamites) preserved in growth position 

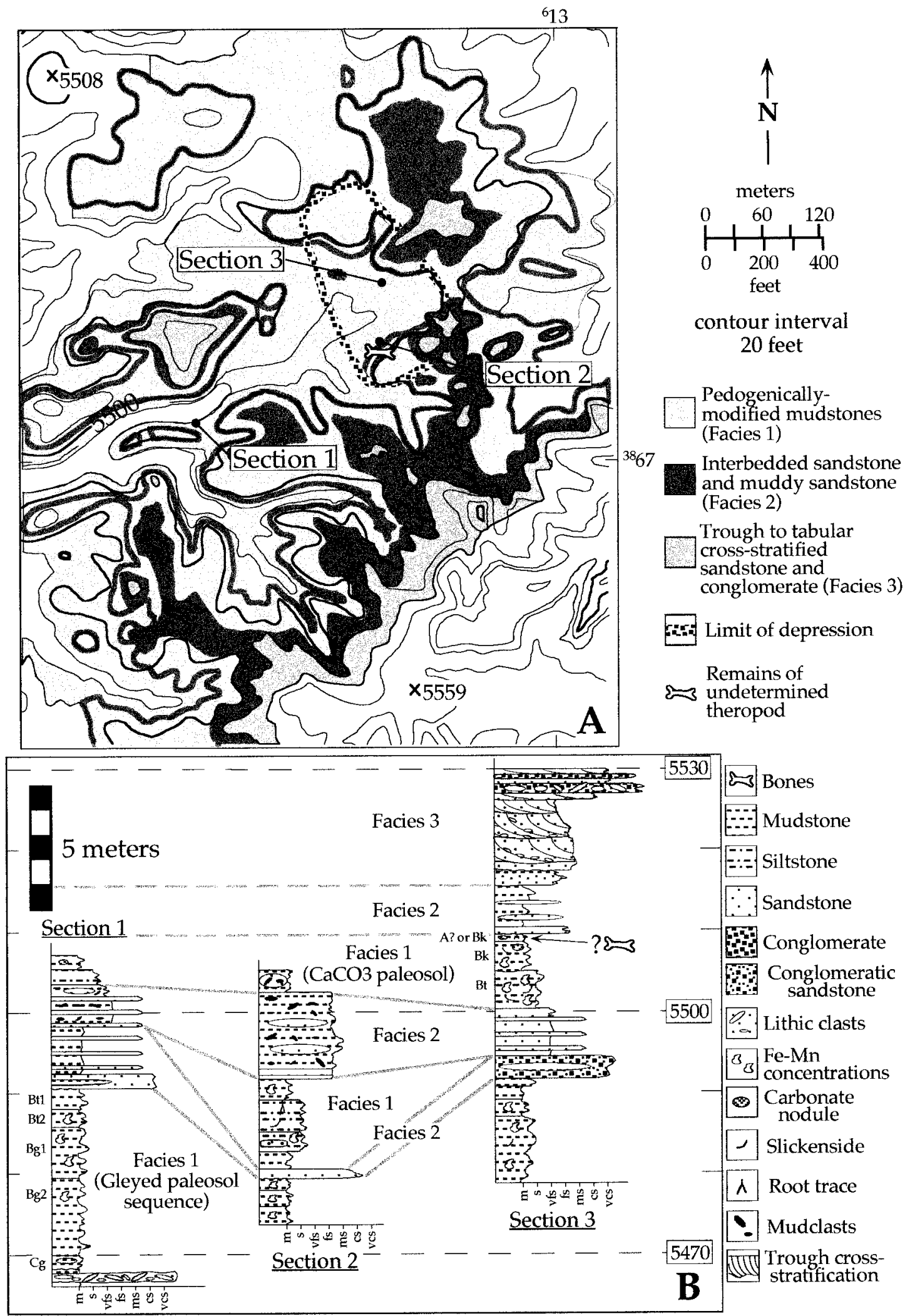

FIGURE 5-Dinosaur Wash locality, PEFO (USGS topographic map, 7.5-minute series, Adamana quadrangle, 1982: entire NE 1/4 SW 1/4 sec. $23 \mathrm{~T} 18 \mathrm{~N}$ R24E). (A) Facies map. (B) Correlated measured sections. Note the depression formed in the gleyed paleosol sequence prior to the deposition of the carbonate-bearing paleosol sequence (clearly seen in the correlated sections). 


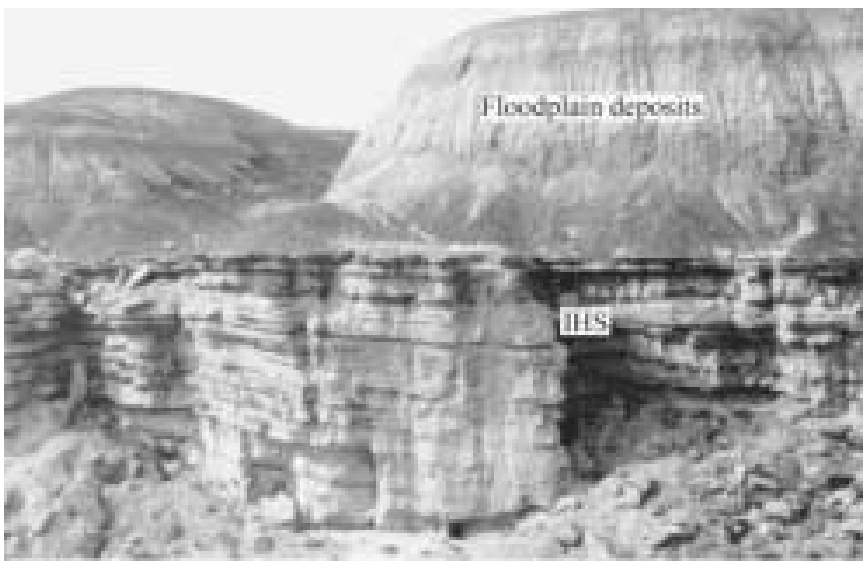

FIGURE 6-Inclined heterolithic strata (IHS) associated with the Newspaper Rock Sandstone, in the Tepees. These 9-m-thick IHS are dipping into a channel scour to the right (not shown on picture).

proximal to the channel (Demko, 1995), reflects that a rich vegetation cover grew in the wet paleoenvironments.

\section{Bones}

The theropod remains consist of vertebrae, teeth, and skull fragments belonging to an undetermined theropod. The disarticulated bones, found on a slope, are presumed to be coming from the blue paleosol horizon (described above; Figs. 5A, 7B) capping the low buttes at the locality, because the abundance of bones is greater on those buttes than anywhere else. Remains of metoposaurs and phytosaurs are also extremely abundant at this locality, accompanied by occasional bones possibly belonging to ornithischian dinosaurs and sphenosuchians.

The bones are preserved in a distal floodplain setting, where sediment accumulation from fine material was de posited by crevasse splays and sheet flooding.

\section{Dinosaur Hill Locality}

The Dinosaur Hill locality is situated in the northern part of PEFO called the Painted Desert (Figs. 1, 2). The facies, consisting of sandstones and mudstones, commonly downcut into underlying ones and grade into other facies laterally, as expected in alluvial deposits (Fig. 8A and $8 \mathrm{~B}$ ).

\section{Fluvial System}

Dinosaur Hill consists of stacked, filled channel scours (Fig. 8B). These scours probably were abandoned during avulsion events and were filled ulteriorly with sandy splay and fine overbank deposits. The finegrained deposits always constitute a major portion of the channel-fill sequences. The only scour for which the width-to-depth ratio is known with certainty is one capped by the bone-bearing blue-colored paleosol (Fig. 8B); all other scours are truncated by other facies. The W/D ratio of the most complete scour is 30:1, a value characteristic of mixed-load streams (Schumm, 1968; Ethridge and Schumm, 1978).

Six-hundred meters to the northwest of the locality and
A

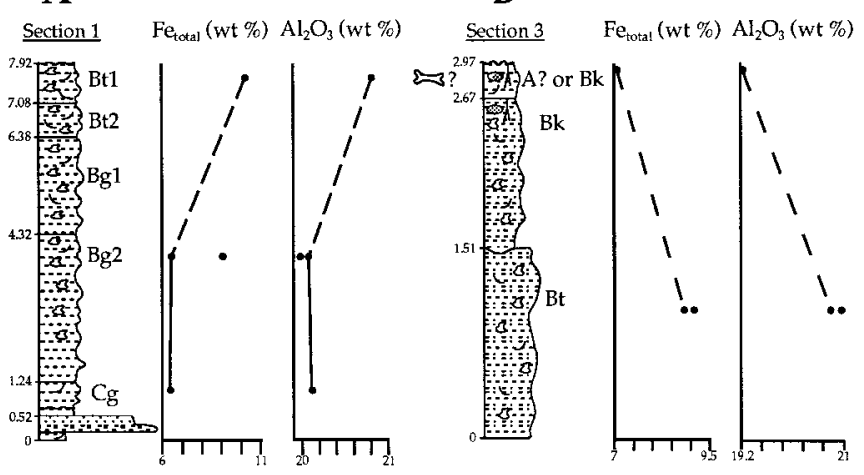

$$
\begin{aligned}
& 2 \text { Conglomerate Conglomeratic sandstone } 3 \text { Fe-Mn concentrations } \\
& \text { Mudstone } \quad 0 \text { Carbonate nodules } \\
& \Lambda \text { Root traces }
\end{aligned}
$$

FIGURE 7-Geochemical profile of the paleosol sequences at Dinosaur Wash. (A) gleyed paleosol sequence. (B) carbonate-bearing paleosol sequences. The iron and aluminum contents of the paleosol sequences are plotted, representing iron oxides/oxihydroxides and clay content in the different horizons. Dashed lines are used when horizons have been recognized by micromorphology, but not analyzed, between two points.

situated stratigraphically $6 \mathrm{~m}$ below the locality, a channel-shaped sandstone body contains well-devel oped IHS. The associated I HS unit is $5 \mathrm{~m}$ thick and exhibits climbing ripple cross-stratification and low-angle trough crossstratification, perpendicular to the dip of the IHS. Thus, the IHS unit is interpreted again as lateral accretion surfaces of a migrating point bar (Allen, 1965; J ackson, 1978; Collinson, 1978; B ridge, 1985).

An exhumed meander belt, consisting of intersecting accretionary ridges with an appreciable curvature, has been documented in the sandstone sheet at the base of Dinosaur Hill (J ohns, 1988). This observation, as well as those made during the course of this study, suggest deposition in a mixed-load, high-sinuosity fluvial system with episodic avulsion events (Collinson, 1978; J ackson, 1978; Bridge, 1985).

Dinosaur Hill (Fig. 8B) reveals a transition from proximal to distal floodplain paleoenvironments in a high-sinuosity fluvial system. In the lower part of the locality, channel and levee deposits are present, attesting to the proximity of the channel. The levee deposits are dissected and overlain by multiple stacked, filled scours. These scours, interpreted as channels, were probably formed during greater-than-bankfull floods or avulsion of the fluvial system. With the return to normal flow, these scours were abandoned and filled with fine-grained sediments. The upper part of the local ity consists of stacked distal crevasse splay deposits.

Paleosols at all stages of maturity are preserved at Dinosaur Hill. Well-devel oped paleosols are found on top of channel-fill sequences, while poorly developed ones are found on splay deposits. This reflects a greater frequency and/or deposit thickness of flood events for the paleosols developed on splays, possibly reflecting proximity to the channel (Bown and Kraus, 1987). The pal eosols present at Dinosaur Hill can be classified into two main categories: 


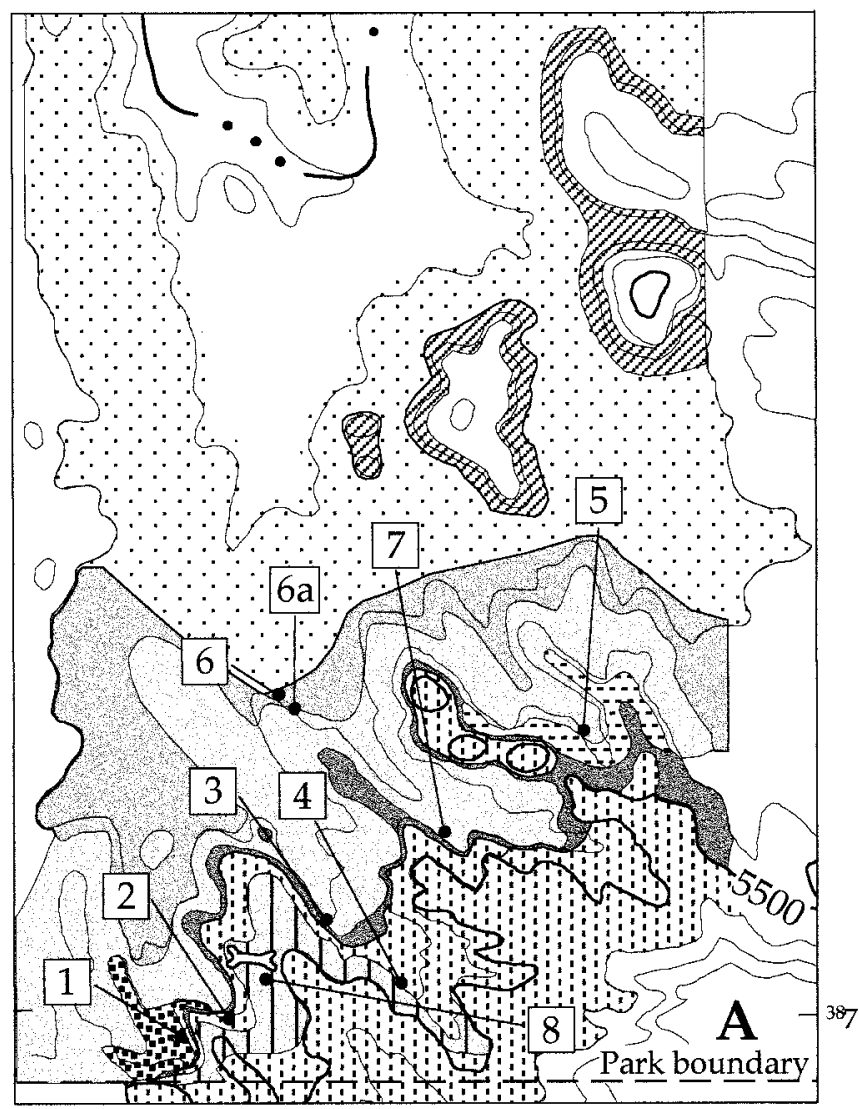

$\therefore$ Trough cross-stratified sandstone (Facies 1)

Interbedded gray arenite and red wacke (Facies 2)

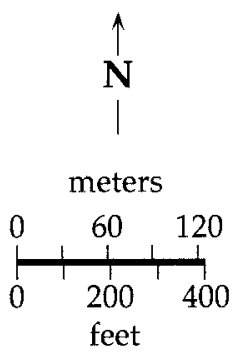

Pedogenically modified red wacke (Facies 3 )

Laminated siltstone and mudstone (Facies 4)

contour interval 20 feet

Interbedded horizontal and trough cross-stratified sandstone (Facies 5)

Cross-stratified sandstone with conglomerate lenses (Facies 6)

$\because$ Fining-upward sequence (Facies 7)

Interbedded cross-laminated

i: to horizontally stratified sandstone and sandy mudstone (Facies 8)

Bone-bearing blue paleosol (part of Facies 4)

\section{Coelophysis bauri} remains

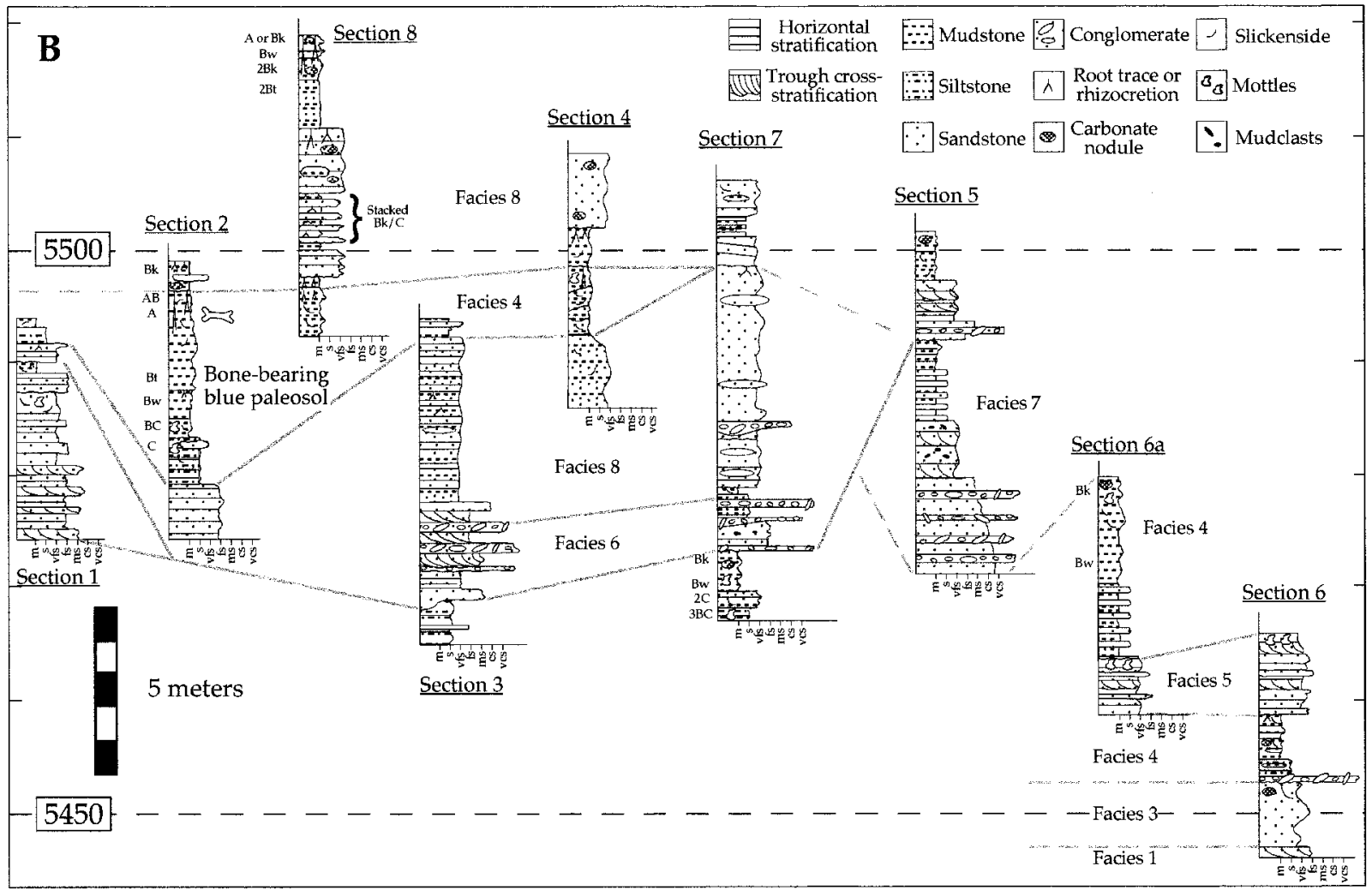

FIGURE 8-Dinosaur Hill locality, PEFO (USGS topographic map, 7.5-minute series, Adamana quadrangle, 1972: SE 1/4 SE 1/4 SW 1/4 sec.18 T19N R24E). (A) Facies map. (B) Correlated measured sections. The bone-bearing blue-colored paleosol is situated at the top of facies 4 , filling the channel scour. 

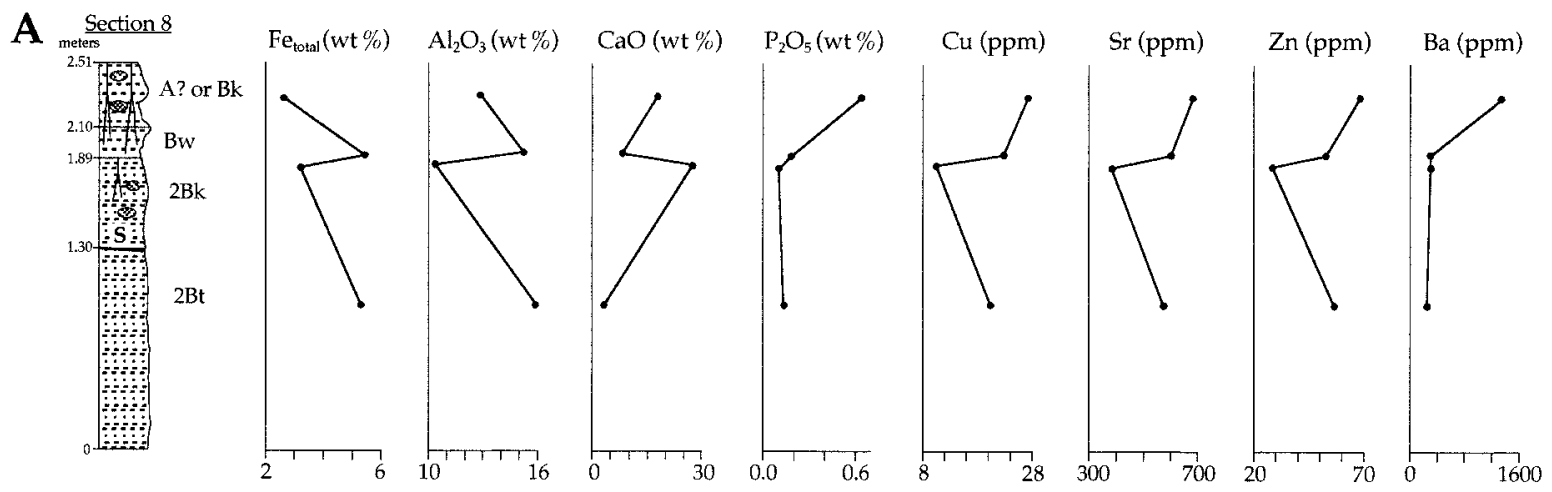

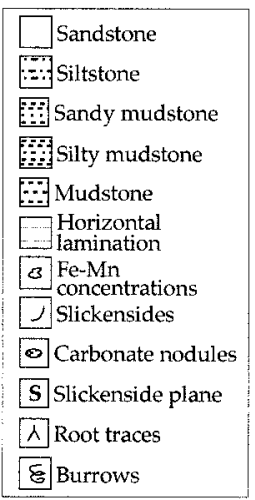

B
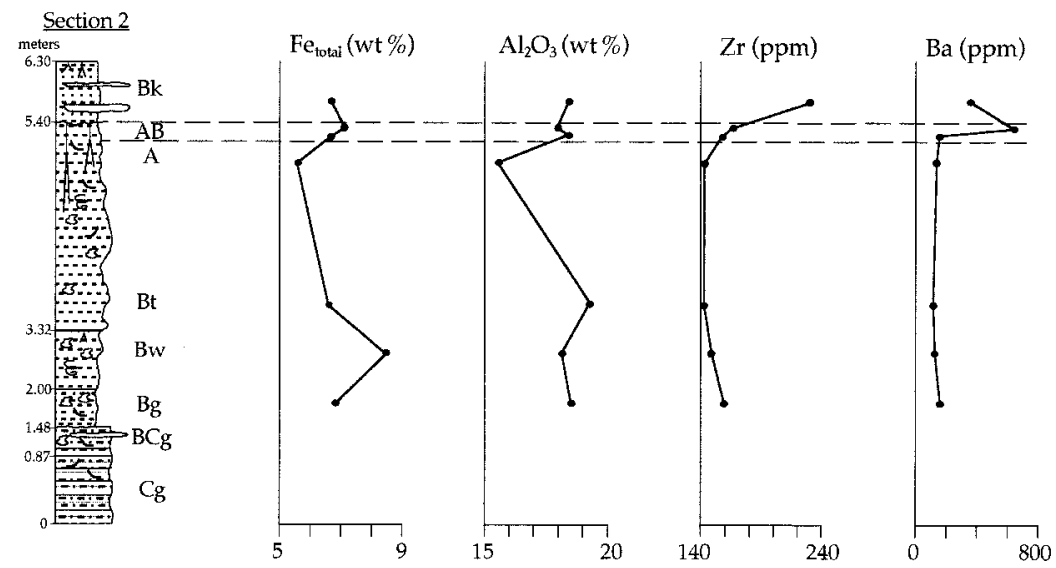

FIGURE 9-Geochemical profiles of the paleosol sequences at Dinosaur Hill. (A) Carbonate-bearing paleosols. The geochemical profile indicates the superposition of 2 paleosols developed on crevasse-splay deposits; the boundary between the two occurs at $1.89 \mathrm{~m}$. (B) Geochemistry of the carbonate-free paleosol.

(1) carbonate-bearing paleosols and (2) carbonate-free paleosols.

\section{Carbonate-bearing Paleosols}

Along with the carbonate-bearing horizons (Bk), carbonate-bearing paleosols tend to have Bt horizons preserved, and possibly even occasional A-horizons, indicated by a lower chroma and enrichment in $\mathrm{P}, \mathrm{Cu}, \mathrm{Sr}$, and $\mathrm{Zn}$ (Fig. 9A). This has been interpreted elsewhere as the geochemical signature of a well-developed organic matter layer in a soil (Aubert and Pinta, 1977; Kabata-Pendias and Pendias, 1984; F eakes and Retallack, 1988). Enrichment in barium also is observed at the top of the uppermost paleosol, a feature common in semi-arid to arid climates (e.g., Madagascar, Aubert and Pinta, 1977). The dual Ba and Sr increase could reflect the duality of the Late Triassic climate: arid periods when barium precipitated in low-solubility sulfates and wet periods when an organic matter layer could develop at the top of the soil, resulting in the accumulation of $\mathrm{Sr}$ and other elements.

These paleosols were developed on dry substrates; the lack of mottling indicates that the soils were not periodically water-saturated. The Bk horizons are indicative of a semi-arid climate under which these soils devel oped. Carbonate nodules, sometimes showing intergrowth with $\mathrm{Fe}$ and $\mathrm{Mn}$ oxides (Fig. 3C), formed in close association with the root traces, sometimes totally surrounding them to form a rhizocretion. Rhizocretions form in response to a change in $\mathrm{pH}$ around roots. Under dry conditions, the root microenvironments are alkaline and carbonate accumulates in close association with the roots. Under wet conditions, the root microenvironments become acidic and prevent carbonate precipitation (Retallack, 1990), but favor $\mathrm{Fe}$ and $\mathrm{Mn}$-oxide accumulation. The intergrowth of carbonateand metallic oxides observed al so is indicative of alternating $\mathrm{pH}$ conditions that occurred in the paleosols. These were formed presumably under the same alternating wet and dry conditions, due to seasonality of precipitation, as those leading to the formation of rhizocretions (Retallack, 1990).

Large rhizocretions consisting of a black core within a calcite-cemented matrix are preserved in the sediments filling a channel scour. Zuber (1990) identified these features as roots of large plants, possibly even trees. This suggests that, in proximity of channels and in scours, conditions were wetter than farther away on the floodplain, thus allowing tree growth.

\section{CarbonatefreePal eosol}

The unique member of this category is a bone-bearing blue-colored paleosol developed on top of a channel filled by crevasse-splay deposits. Carbonate nodules are ubiquitous in all the paleosols of Dinosaur Hill, except in theblue paleosol for which the occurrence of carbonate nodules was not recorded in any of the studied sections (Fig. 8B). Murry and Long (1989) described the presence of carbon- 
ate nodules in the bone bed, but the exact location of their measured section is unknown.

The bone-bearing, blue-colored paleosol sequence is developed on a 5.5-m-thick mudstone and siltstone interval in the center of a filled channel ( $\mathrm{Fig}$. 8B). This pal eosol sequence consists of an uppermost bluish (5RP 6/2) mudstone horizon ( $2.6 \mathrm{~m}$ thick) in which bones arefound, a medial weak red (10R 4/3) mudstone horizon (0.8 mthick) underlain by gleyed horizons of mudstone and siltstone, the basal unit of which is a finely laminated siltstone. Dusky red mottles (10R 3/2) are present through the profile, even in the upper part of the laminated siltstone. The $\mathrm{Zr}$ content of the profile (Fig. 9B) shows that the blue-colored horizon has a uni form composition, while the other horizons have a different $\mathrm{Zr}$ content. This indicates that the profile was developed on parent materials with different compositions, probably resulting from several depositional episodes that brought new material to the developing paleosol.

The blue-colored horizon is heavily bioturbated, contains angular to subangular blocky peds, and exhibits slickensides. Root traces are abundant and can be traced unequivocally to a depth of $1.2 \mathrm{~m}$ from the top of the horizon. The root traces are filled by clastic material originating from above. The top of the blue-col ored horizon undergoes a subtle, gradual col or change in the last $0.2 \mathrm{~m}$ before reaching the erosional contact with the overlying facies. This transitional zone goes from a reddish blue at its base to a bluish red at its top.

In general, the upper section of the blue-col ored horizon shows sesquioxide depletion (Fig. 9B). The accumulation of sesquioxides in the transitional zoneis dueto compound pedogenesis (Bown and Kraus, 1981a), when features of a horizon are superimposed on the features of a preexisting horizon. In this case, the development of the red paleosol above the blue-colored horizon has modified the original pedogenic features of the uppermost blue-col ored horizon. Elements, leached from the developing paleosol of the overlying strata, accumulated in the upper part of the blue-colored horizon, resulting in an increase in $\mathrm{Fe}_{\text {total }}$ and $\mathrm{Al}_{2} \mathrm{O}_{3}$ and creating the transition zone. The gradual upward enrichment in barium observed in the blue-colored horizon culminates with a high $\mathrm{Ba}$ content at thetop of the transition zone (Fig. 9B). The Ba enrichment observed here is thought to reflect a difference in composition of the parent material rather than semi-aridity because similar enrichment trends are observed for $\mathrm{Zr}, \mathrm{Nb}, \mathrm{Y}$, and $\mathrm{Sr}$.

Theilluviation of clay and sesquioxides in thelower part of the blue-colored horizon (Fig. 9B) also is related to compound pedogenesis. Episodic flood events incorporated sediment as the paleosol profile was forming, resulting in the extreme thickness of the blue horizon. The original de pleted-nature of the A-horizon in the lower part of the blue-colored horizon was overprinted by illuvial features when the upper part of the blue-colored horizon developed, resulting in a "secondary" Bt horizon (see Birkeland, 1974; Retallack, 1983; Kraus and Bown, 1986).

The occurrence of $\mathrm{Fe}$ and $\mathrm{Mn}$ concentrations in the profile reflects alternating periods of oxidizing and reducing conditions due to water-table fluctuation. The periodicity of these fluctuations is unspecified. The gleyed colors of the basal horizons reflects water saturation. Root traces infiltrating deep into the ground support the idea of a sea- sonally water saturated paleosol as plants growing in arid areas tend to have surficial root systems to collect water from precipitation (Cannon, 1911; Donahue et al., 1971). Therefore, it seems that the channel scour on which the bone-bearing paleosol developed was a localized wet area on the floodplain.

\section{Bones}

The theropod remains, ascribed to Coelophysis bauri (Padian, 1986), consist of an almost complete pelvis and complete, articulated hindlimbs. The partial, associated but disarticulated axial skeleton of a crocodylomorph also was discovered in the same strata, al ongside remains of a rauisuchian, a large gomphodont cynodont, phytosaurs, aetosaurs, ornithischian and saurischian dinosaurs, and disarticulated but associated metoposaur skeletons ( $L$ ong and Padian, 1986; Padian, 1986, 1990; Murry and Long, 1989; Parrish, 1989, 1991; Hunt, 1998).

\section{Dinosaur Hollow Locality}

The Dinosaur Hollow locality is situated in thenorthern end of PEFO, close to the Chinde Point viewpoint (Figs. 1, 2). The strata dip no more than a few degrees to the southeast. This locality consists of two superposed fining-upward sequences capped by a major reworked-tuff sandstone layer, the Black Forest Bed (Fig. 10).

\section{Fluvial System}

A multistorey sandstone sheet is exposed at Dinosaur Hollow. Laterally extensive multistorey sandstone sheets are deposited when the avulsion rate of a flavial system is high relative to the basin subsidence rate (Blakey and Gubitosa, 1984). In the lower storey, two channel-form sandstone bodies exhibit IHS with a pal eoflow direction perpendicular to dip. J ohns (1988) also reported several lateral accretion units associated with a well-developed ridge-and-swale topography for this sandstone sheet. These two features indicate deposition by point bars in a highly sinuous river system (Allen, 1965; Collinson, 1978; J ackson, 1978; Bridge, 1985).

Although fining-upward sequences also are recognized in braided fluvial systems (e.g., Cant and Walker, 1976, 1978), these are different from the one preserved at Dinosaur Hollow. Fining-upward sequences of braided rivers are composed of $80 \%$ to $100 \%$ of channel, bar, and sandflat deposits, the remainder being small-scale crossbedded sandstone and floodplain deposits (Cant, 1978). The Dinosaur Hollow sequences consist of $50 \%$ or less sandstone, and no sand-bar or sandflat deposits were recognized. Paleocurrent variability is relatively low at Dinosaur Hollow (J ohns, 1988; Therrien, 1999).

All these observations are indicative of deposition in a frequently avulsing, high-sinuosity fluvial system rather than in a low-sinuosity, braided system. In contrast, J ohns (1988) interpreted the deposits of the conglomerate present in the second sandstone sheet as resulting from the migration of longitudinal bars that were overlain by migrating dunes of sand-sized material, during a period of waning flow or increased water depth. 


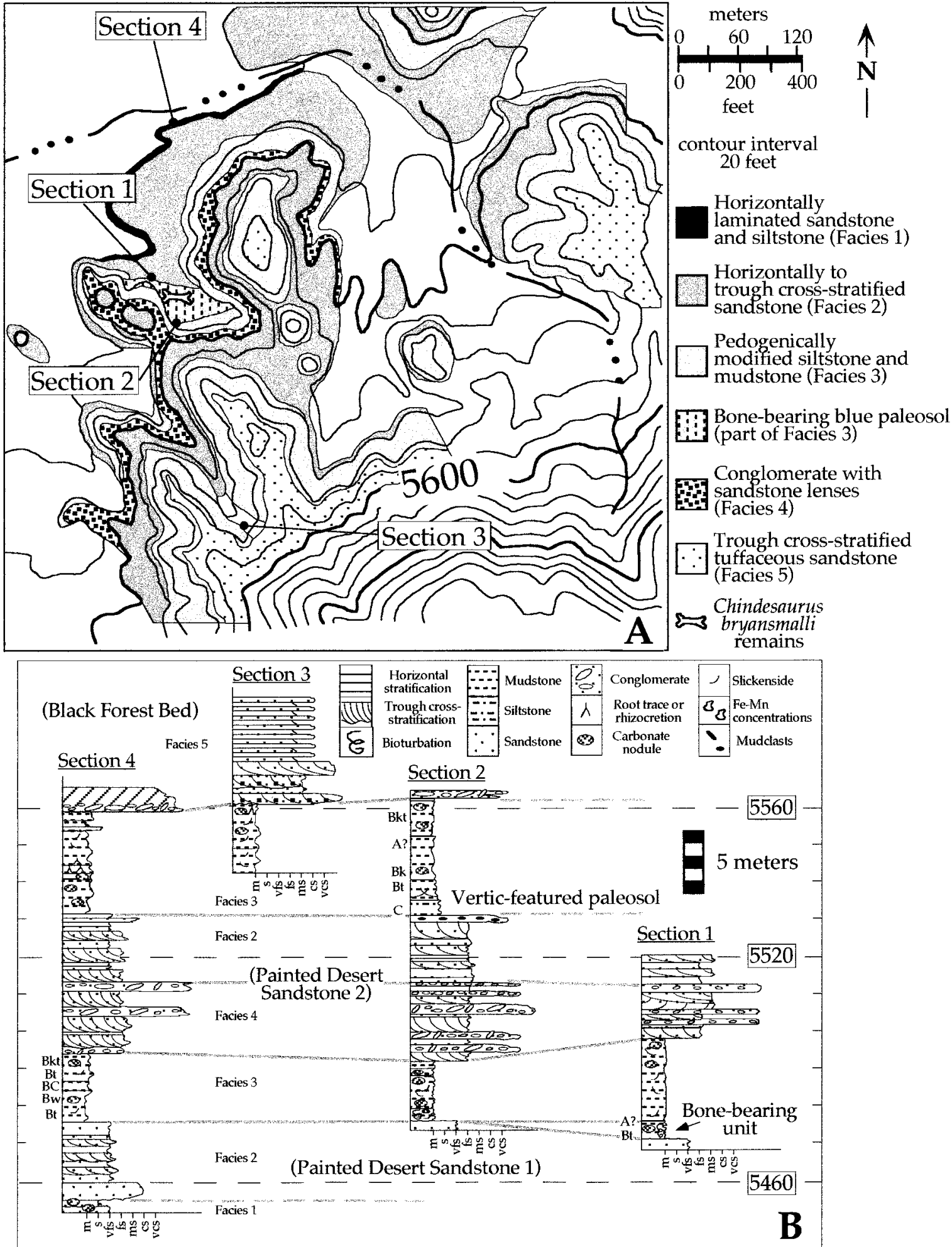

FIGURE 10-Dinosaur Hollow locality, PEFO (USGS topographic map, 7.5-minute series, Adamana quadrangle, 1972: NE 1/4 NE 1/4 SW 1/ 4 sec. 33 T20N R24E). (A) Facies map. (B) Correlated measured sections. Painted Desert Sandstone 1 and 2 are equivalent to Billingsley's (1985a, b) Painted Desert Sandstone 3 and 4, respectively. 


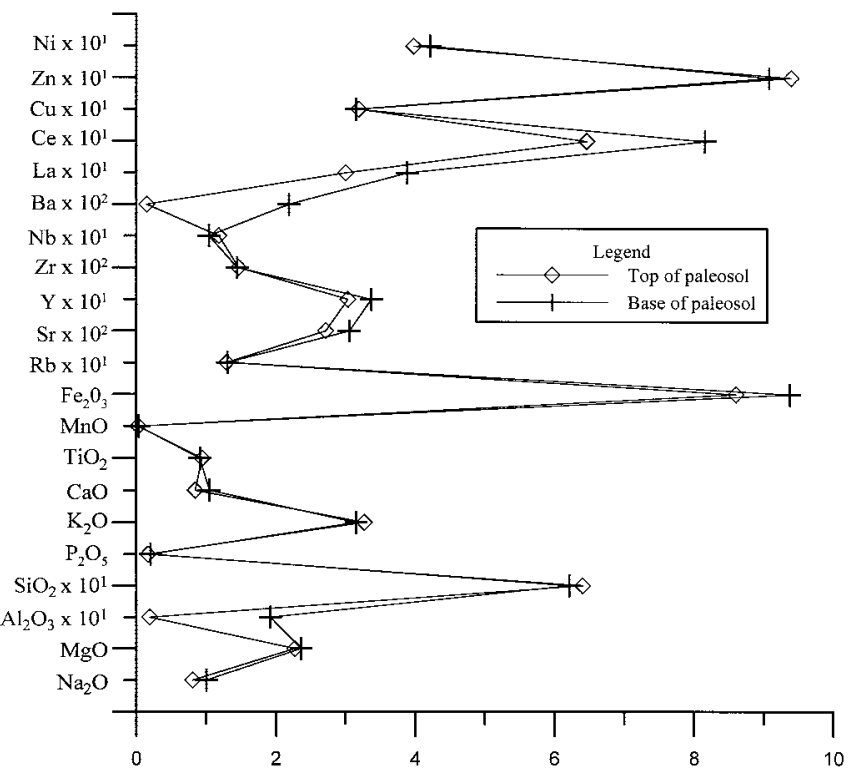

FIGURE 11-Geochemical composition of the bone-bearing blue-colored paleosol at Dinosaur Hollow. The units for the $\mathrm{X}$ axis vary: weight percent (wt \%) values for major elements $\left(\mathrm{Na}_{2} \mathrm{O}\right.$ through $\left.\mathrm{Fe}_{2} \mathrm{O}_{3}\right)$ and ppm values for trace elements ( $\mathrm{Rb}$ through $\mathrm{Ni}$ ).

\section{Paleosols}

The mudstone intervals preserved at Dinosaur Hollow represent cumulative paleosols that werebuilt by sporadic addition of material to the developing profile (Fig. 10B). The pal eosols were formed in a pal eoenvironment subjected to alternating wet and dry periods. The compound nature of the clay/iron-oxide coatings (Fig. 3D) indicates that clay translocation occurred several times, possibly related to seasonal precipitation. Carbonate nodules and calcic horizons (BK) require a semi-arid climate to develop. The cl ose association of intergrown carbonate nodules and ferruginous oxides with root traces is indicative of alternating dry and wet conditions to which the plants were exposed (see above). If modern anal ogs are any guide, vertic features in this paleosol sequence (including pseudoanticlines) al so indicate periods of water deficit during the year (e.g., Dudal and Eswaran, 1988; Wilding and Tessier, 1988). The gl eyed horizons with $\mathrm{Fe}$ and $\mathrm{Mn}$ concentrations indicate that the base of paleosols could have been saturated for a certain part of the year, probably the rainy season. However, the presence of vertic features in this interval indicates that the paleosol underwent severe wetting and drying, presumably related to the absence of water in the paleosol during the dry season. Since the gleyed horizons overlie a major sandstone sheet and that no gleyed horizons are found in thestratigraphically-lower paleosols (Fig. 10), the groundwater may have flowed through the coarse sediment of the sandstone sheet, acting as a perched aquifer.

Bones are found in a unique, localized bluish (10R 4/2) pedogenically modified mudstone situated immediately above the lowest sandstone sheet exposed at Dinosaur Hollow (Fig. 10). Correlation of the stratigraphic sections reveals that the blue-colored layer rests in a shallow depression. The blue-colored mudstone has a maximum thickness of $1.8 \mathrm{~m}$ and thins out laterally, probably reflect- ing the shape of the depression. The mudstone is bioturbated, contains iron nodules, preserves root traces surrounded by purple hal oes, and has numerous slickensides. Light purple (10P 7/2) redoximorphic features are also occasionally observed in this unit, representing alternating redox conditions in the paleosol.

The limited exposure of the blue-col ored paleosol prevented extensive investigation of the profile; however, it was possi ble to analyze the geochemistry of samples from the top (bluish mudstone 10R 4/2) and base (red mudstone 10R 5/2) (Fig. 11). The results reveal that the top of the unit is depleted in sesquioxides $\left(\mathrm{Al}_{2} \mathrm{O}_{3}\right.$ and $\left.\mathrm{Fe}_{2} \mathrm{O}_{3}\right)$, but especially in clay (represented by $\mathrm{Al}_{2} \mathrm{O}_{3}$ ). Micromorphology of the uppermost part of the blue-colored paleosol confirms that accumulation of clay and Fe-Mn is noticeably absent and extensive bioturbation is observed, possibly representing an A-horizon. Clay and oxide coatings are observed at the base of the bone-bearing paleosol, which is interpreted as a Bt horizon. Rare, very small $(2 \mathrm{~mm})$ carbonate nodules are also present in the lower horizon of the profile.

\section{Bones}

The disarticulated remains of Chindesaurus bryansmalIi (Murry and Long, 1989; al so see Long and Murry, 1995) consist of cervical, dorsal, and caudal vertebrae, ribs, neural and haemal arches, and pieces of femora and tibia. Fragmentary remains of a rauisuchian were recovered from the same bone-bearing blue-colored layer (Long, 1985; Hunt, 1998).

\section{DISCUSSION}

The most complete theropods of PEFO commonly are preserved in distinctive bluish mudstones (Table 1). A similar preferential preservation is reported in the Lower Eocene Will wood Formation of Wyoming where bones are concentrated in A-horizons of spodosols (Bown and Kraus, 1981b), and in the Kayenta Formation of Arizona, in which bones are exclusively preserved in blue-colored mudstones (Clark and Fastovsky, 1986).

The bone-bearing paleosols of PEFO share five diagnostic characteristics: (1) bluish gleyed color; (2) bioturbation; (3) depletion in aluminum and iron, and low manganese content; (4) position directly above sesquioxiderich horizons showing evidence of clay illuviation; and 5) Fe and Mn concentrations (mottles) occurring in the paleosol profile. The bluish color and the Fe-Mn concentrations areindicators of changing water-saturation conditions in the paleosols, varying between oxidizing and reducing conditions. Sesquioxides were eluviated from the top of the paleosols and accumulation occurred in the lower horizons of the profile. Therefore, the bone-bearing blue-colored layers are interpreted as A-horizons (depleted in aluminum and iron coatings) of pal eosols that underwent alternating oxidizing and reducing conditions, presumably due to seasonal changes in water-saturation.

Although fossils are found commonly in blue-col ored paleosols, not all blue-colored paleosols represent the same depositional setting. The blue-colored paleosols of Dinosaur Hill and Dinosaur Hollow were devel oped on fine material filling a restricted topographic depression, whilethe 
TABLE 1-Characteristics of the bone-bearing paleosol profiles present at the theropod localities of PEFO

\begin{tabular}{|c|c|c|c|c|c|c|c|c|}
\hline Locality & Horizon & $\begin{array}{l}\text { Thick- } \\
\text { ness }\end{array}$ & Matrix color & $\begin{array}{l}\text { Redoximorphic } \\
\text { features }\end{array}$ & $\begin{array}{l}\text { Cla y } \\
\text { coat- } \\
\text { ings }\end{array}$ & Carbonates & $\begin{array}{l}\text { Slidken- } \\
\text { sides }\end{array}$ & Notes \\
\hline \multirow[t]{2}{*}{ Dinosaur Wash } & $\begin{array}{l}\mathrm{A} ? \text { or } \mathrm{Bk} \\
\mathrm{Bk}^{*}\end{array}$ & $\begin{array}{l}0.30 \mathrm{~m} \\
1.16 \mathrm{~m}\end{array}$ & $\begin{array}{l}10 \mathrm{~PB} 6 / 2 \\
2.5 \mathrm{P} 4 / 2\end{array}$ & $\begin{array}{l}\text { Rare } \\
\text { Common (2.5P 5/2) }\end{array}$ & $\begin{array}{l}\text { No } \\
\text { No }\end{array}$ & $\begin{array}{l}\text { Yes } \\
\text { Yes* }\end{array}$ & $\begin{array}{l}\text { Yes } \\
\text { Yes }\end{array}$ & $\begin{array}{c}\text { Bioturbation. Organic matter? } \\
\text { *Carbonate nodules appear at } \\
\text { the top of the horizon. Bio- } \\
\text { turbation. Organic matter? }\end{array}$ \\
\hline & Bt & $1.51 \mathrm{~m}$ & 10R $3 / 6$ & Common (2.5P 6/6) & Yes & No & Yes & Bioturbation? \\
\hline \multirow[t]{5}{*}{ Dinosaur Hill } & A & $2.60 \mathrm{~m}$ & $5 \mathrm{RP} 6 / 2$ & $\begin{array}{l}\text { Rare to Common } \\
\quad(10 \mathrm{R} 3 / 2)\end{array}$ & No & No & Yes & $\begin{array}{l}\text { Compound pedogenesis at the } \\
\text { top ( } \mathrm{AB} \text { horizon) and at the } \\
\text { base (Bt horizon) }\end{array}$ \\
\hline & Bw & $0.80 \mathrm{~m}$ & $10 R 4 / 3$ & Common (10R 3/4) & No & No & Yes & Bioturbation \\
\hline & $\mathrm{Bg}$ & $0.52 \mathrm{~m}$ & 10R 4/1 & Common (10R 3/2) & No & No & Yes & Bioturbation? \\
\hline & $\mathrm{BCg}$ & $0.65 \mathrm{~m}$ & 10R 6/1 & Common (10R 4/1) & No & No & Few & $\begin{array}{l}\text { Same material as below, ex- } \\
\text { cept for appearance of mot- } \\
\text { tles and lack of sedimentary } \\
\text { structures }\end{array}$ \\
\hline & $\mathrm{Cg}$ & $0.87 \mathrm{~m}$ & 10R $6 / 1$ & No & No & No & Rare & Parallel laminations \\
\hline Dinosaur Hollow & $\begin{array}{l}\text { A } \\
\text { Bt }\end{array}$ & $\begin{array}{l}0.80 \mathrm{~m} \\
1.00 \mathrm{~m}\end{array}$ & $\begin{array}{l}\text { 10R } 4 / 2 \\
\text { 10R } 5 / 2\end{array}$ & $\begin{array}{l}\text { Common (10P 7/2) } \\
\text { Common (10P 7/2) }\end{array}$ & $\begin{array}{l}\text { No } \\
\text { Yes }\end{array}$ & $\begin{array}{l}\text { No } \\
\text { Rare, small }\end{array}$ & $\begin{array}{l}\text { Yes } \\
\text { Yes }\end{array}$ & $\begin{array}{l}\text { Bioturbation } \\
\text { Bioturbation? }\end{array}$ \\
\hline
\end{tabular}

Dinosaur Wash blue-colored horizon forms a laterally extensive unit, possibly related to the filling of a large paleovalley formed in the region (Demko, 1995; Kraus and Bown, 1986). The preservation of the A-horizons of these paleosols might be related to their low topographic position, which could have sheltered them from erosion. The concentration of vertebrate remains in paleosols capping channel-fill sequences is typical of the preservation bias of bones in localized depressions on the floodplain, where rapid burial occurs (Behrensmeyer, 1987). Other pedogenically-modified channel fills were observed in the Dinosaur Wash region and at Dinosaur Hill (Fig. 1; see Kraus and Bown, 1986; Kraus and Middleton, 1987), but none contained nearly as many vertebrate remains as the bluecolored paleosol of Dinosaur Hill. Therefore, the blue-colored paleosols of PEFO must represent a real case of preservational bias for vertebrate remains. But why arefossils preferentially preserved in relatively uncommon blue-colored paleosols rather than in the more common and widespread red or purple paleosols?

The answer may lie, at least in part, in the fact that bone-bearing horizons represent A-horizons; therefore, it is expected that bones will be preserved in those surficial horizons. The accumulation of bones at different levels within the blue-col ored horizons reflects the burial and incorporation into the developing profile of autochthonous, attritional bone assemblages by episodic depositional events. The degree of disarticulation and incompleteness of the skeletons can be attributed to trampling, scavenging, and putrefaction prior to burial (Behrensmeyer et al., 1979; al so see Koster, 1987).

Moreover, preservation may have been enhanced by topography. The blue-colored paleosols devel oped in wet areas on the floodplain where drainage was impeded. Sources of water were probably common and relatively easy to access in that setting. In the cases of Dinosaur Hill and Dinosaur Hollow, the wetter conditions of slow-filling channels, probably resulting from surface and ground-water concentration in a topographic depression, were favorable for plants and animals living in the semi-arid climate of the Late Triassic. Creatures inhabiting the area probably converged toward those wet areas of the floodplain and interacted, contributing to a time-averaged attritional vertebrate assemblage representative of the original communities (Behrensmeyer, 1987). The blue-col ored paleosol se quence at Dinosaur Wash represents wet conditions on the floodplain, although its position over a hydromorphic, gleyed paleosol and the occurrence of carbonate nodules record a transition to drier conditions.

\section{Coelophysis Quarry at Ghost Ranch}

The most famous locality for the preservation of Chinle theropods is not PEFO but is, undoubtedly, at Ghost Ranch, New Mexico. The Codophysis quarry contains a paucispecific assemblage of several thousand individuals, many of which are articulated to semi-articulated (Colbert, 1947, 1964, 1989, 1995; Schwartz and Gillette, 1994; Hunt and Lucas, 1993; Sullivan et al., 1996; Downs and Davidge, 1997; A. Downs, personal communication, J uly 1998). Our discussion of early North American theropod preservation, therefore, must address the Ghost Ranch theropod assemblage in the context of what we now know of theropod preservation in PEFO.

The Cod ophysis quarry was cl osed and covered with debris following the last excavation in 1985. For this study, a trench was dug in the debris covering the site to expose part of the quarry face, allowing us to measure a section and describe the stratigraphic units (Fig. 12). Given the limited exposure of the quarry, we rely on previous work (mostly Schwartz and Gillette, 1994) as a primary source of information on the taphonomy of the site.

\section{Fluvial System}

Diagnostic features of fluvial systems were not visi bleat the Coel ophysis quarry, and some ambiguity exists regarding the interpretations of the sedimentary environments preserved therein. Dubiel (1989c) interpreted the depositional environment of this interval as a periodically flood- 


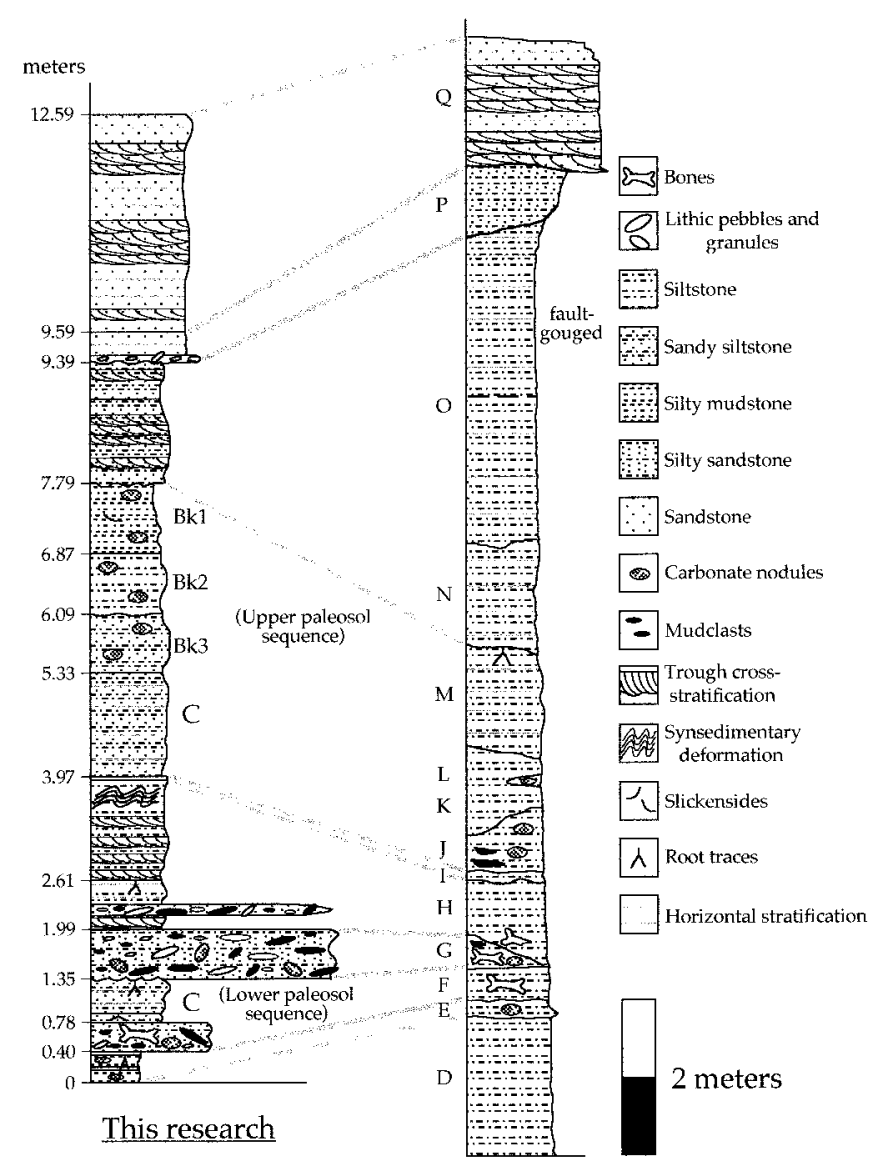

Schwartz and Gillette (1994)

FIGURE 12-Comparison of stratigraphic sections of the Coelophysis quarry. To left, this study; to right, study by Schwartz and Gillette (1994).

ed and exposed lacustrine mudflat with marginal channels filled by fine sediment. Trinh et al. (1996) interpreted deposition in a meandering river system on the basis of paleocurrent variability of the cross-stratification present at the quarry.

\section{Paleosols}

Two paleosol sequences developed on a silty parent material are present at the Coelophysis quarry: a well-developed paleosol at the top of the quarry and a weakly developed one separating the two bonebeds (Fig. 12). In the highest paleosol sequence ( $\mathrm{C}$ and $\mathrm{BK}$ horizons situated above the bonebeds; Fig. 12), the most obvious features seen at the outcrop scale are carbonatenodules. The upper paleosol sequence, which developed on siltstone, exhibits calcic (Bk) horizons with an undifferentiated b-fabric. Crystalline calcite infillings also are observed in the BK horizons. Carbonate nodules exhibit internal rings of $\mathrm{Fe}$ oxides (Fig. 4), indicating variation in $\mathrm{pH}$ conditions of the paleosols. These features strongly reflect development in a semi-arid climate with alternating wet and dry periods.

The lowest paleosol sequence, a $C$ horizon with root traces situated between the bonebeds (Fig. 12), does not contain carbonate nodules and preserves its internal sed- imentary structure. Close inspection reveals that it is composed of two sedimentary units: (1) a thin $(12 \mathrm{~cm})$ muddy siltstone unit conformably overlying the conglomeratic siltstone in which the skel etons are found; and (2) a thicker superjacent $(45 \mathrm{~cm})$ sandy siltstone. Mudcracks (Schwartz and Gillette, 1994) and root traces dissect the fine lamination of both siltstones, and are the only evidence of subaerial exposure. This indicates that two very brief periods of exposure occurred following the deposition of the first bonebed. Rapid burial probably prevented pedogenic processes from modifying the sediment. The lower paleosol, therefore, supports earlier claims, based on paleontologic evidence, that the Ghost Ranch death assemblage was formed relatively quickly (Schwartz and Gillette, 1994) and that the first bonebed (F) represents a single, catastrophic event.

\section{Bones}

The Cod ophysis bauri remains are reported to be concentrated in two localized, shallow, U-shaped sandy siltstone beds ( $\mathrm{F}$ and $\mathrm{G}$ ) with erosional bases, containing lithic fragments, detrital carbonate nodules, and mudclasts (Schwartz and Gillette, 1994). Bed F is the main bonebed, containing most bones and all the complete skeletons, while bed $G$ represents the remobilization of el ements by a subsequent erosive event (Schwartz and Gillette, 1994). Study of the quarry reveals that the carcasses are concentrated in the conglomeratic units of the fossiliferous beds. The carcasses are stacked against one another (A. Downs, personal communication, J uly 1998), rather than complexly intertwined as previously reported by Schwartz and Gillette (1994). The close association of the bones with the coarsest part of the bonebeds, combined with the Ushaped geometry of the siltstone beds, indicates that the carcasses were concentrated at the base of channeled, high-energy flow events such as proximal crevasse channels (sensu Bridge [1985], as proposed by Schwartz and Gillette [1994]), and were then covered by fine material (e.g., lowest pal eosol sequence). A comprehensive description of the orientation of bone fragments and carcasses is presented by Schwartz and Gillette (1994).

\section{Comparison of PEFO and Ghost Ranch}

The Ghost Ranch setting is distinct from the PEFO localities (Table 2). The paleosols present at the Cod ophysis quarry indicate alternating dry and wet periods, but they do not exhibit features suggestive of water-saturation fluctuation as seen in PEFO. Clay illuviation is minimal at Ghost Ranch, possibly related to the siltier nature of the parent material, or possibly reflective of higher rates of sediment accumulation.

The theropod skeletons at Ghost Ranch are not preserved in well-developed paleosols (Schwartz and Gillette [1994] interpreted them as having accumulated in a proximal crevasse channel), while those in PEFO are found in paleosols. This indicates that Coelophysis carcasses at Ghost Ranch represent a post-mortem concentration due to fluvial processes; the carcasses were transported for a relatively short distance, stranded due to the falling stage of the flow and buried rapidly during a single event (Schwartz and Gillette, 1994). In PEFO, thearticulated to 
TABLE 2-Taphonomic, sedimentologic, and paleopedologic comparison of the four theropod localities studied. Note the lack of herbivores in the Coelophysis quarry. ${ }^{1}$ Colbert $(1947,1964,1989,1995),{ }^{2}$ Schwartz and Gillette (1994), ${ }^{3}$ Hunt and Lucas (1993), ${ }^{4}$ Sullivan et al. (1996), ${ }^{5}$ Downs (personal communication, 1999), ${ }^{6}$ Padian (1986), ${ }^{7}$ Murry and Long (1989), 8 Parrish (1991), ${ }^{9}$ Hunt (1998), ${ }^{10}$ Padian (1990), ${ }^{11}$ Long (1985), ${ }^{12}$ Trinh et al. (1996).

\begin{tabular}{|c|c|c|c|c|}
\hline & Coel ophysis quarry & Dinosaur Wash & Dinosaur Hill & Dinosaur Hollow \\
\hline $\begin{array}{l}\text { Vertebrate remains/Abun- } \\
\text { dance }\end{array}$ & $\begin{array}{l}\text { Articulated to associ- } \\
\text { ated/Plentiful }{ }^{1,2}\end{array}$ & $\begin{array}{l}\text { Disarticulated and associ- } \\
\text { ated(?)/Common }\end{array}$ & $\begin{array}{l}\text { Articulated to associated/ } \\
\text { Common }\end{array}$ & Associated/Rare ${ }^{9}$ \\
\hline Composition of locality & $\begin{array}{l}\text { Paucigeneric; } \\
\text { Coelophysis }^{1,2}, \\
\text { rauisuchians } \\
\text { (Postosuchus }^{3} \text {, } \\
\text { sphenosuchians }^{3}, \\
\text { phytosaurs } \\
\text { (Redondasaurus }^{3,4} \text { ), } \\
\text { and undescribed } \\
\text { primitive } \\
\text { archosauromorph }\end{array}$ & $\begin{array}{l}\text { Multigeneric; undet. } \\
\text { theropod, rauisuchian?, } \\
\text { ornithischian?, } \\
\text { phytosaurs, and } \\
\text { metoposaurs }\end{array}$ & 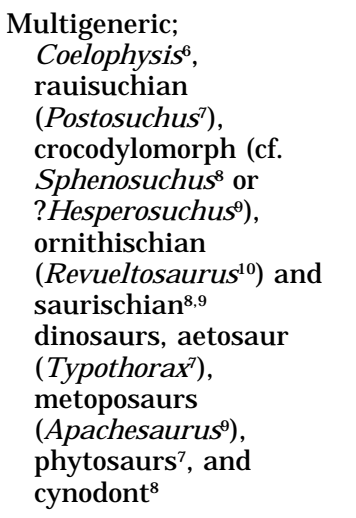 & $\begin{array}{l}\text { Paucigeneric?; } \\
\text { Chindesaurus } \\
\text { rauisuchian }\end{array}$ \\
\hline Preservation environment & $\begin{array}{l}\text { Proximal crevasse } \\
\text { channels }\end{array}$ & Paleosol/distal floodplain & Paleosol/channel scour & Paleosol/depression \\
\hline Fluvial system & Meandering rivers ${ }^{12}$ & Meandering rivers & Meandering rivers & Meandering rivers \\
\hline Climate/paleoenvironment & Semi-arid/dry & $\begin{array}{l}\text { Semi-arid/transitional wet } \\
\text { to dry }\end{array}$ & $\begin{array}{l}\text { Semi-arid/wet in proximi- } \\
\text { ty of channels }\end{array}$ & $\begin{array}{l}\text { Semi-arid/annual periods } \\
\text { of water-deficit }\end{array}$ \\
\hline
\end{tabular}

semi-articulated state of the skel etons indicates that postmortem transport was minimal. The PEFO theropods may have congregated in wetter areas on the floodplain, thus resulting in the time-averaged attritional vertebrate assemblages observed.

The uniqueness of the Coelophysis quarry is strengthened by its catastrophic mortality assemblage: (1) skele tons representative of the age distribution of a population, but lack very young and very old individuals (Covey, 1993); (2) complete skeletons of the same creature are abundant; and (3) the preservational quality of the carcasses is relatively uniform. Differential styles of preservation are reported between the upper and lower halves of some skeletons (A. Downs, personal communication, J uly 1998). This is suggestive of a two-phase burial history where the carcasses were covered by sediment but some parts were left exposed prior to complete burial (Sternberg, 1970). This interpretation is corroborated by the recognition of two, thin sedimentary units overlying themain bonebed (see above; Fig. 12 lower paleosol).

No evidence supporting the inferences of large-scale herding or of cannibalism of Coel ophysis, made on the basis of the Ghost Ranch setting (Col bert, 1989, 1995), is pre served in PEFO. This lack of evidence could be due to: (1) relatively poor preservational conditions of the PEFO specimens; (2) toosmall a sampleprovided by thelocalities studied; or (3) the fact that Coelophysis quarry represents unique, catastropherelated behavior in theropods. Cannibalism has very little potential of being detected in an attritional assemblage. The remains of a theropod's last meal are unlikely to be preserved in an environment where burial does not immediately follow death; trampling, scavengers, putrefaction, and even pedogenic pro- cesses can destroy small bones (Koster, 1987). Moreover, inferences of cannibalism in Coe ophysis bauri were made on the basis of only two largespecimens (AMNH 7223 and 7224; Col bert, 1989, 1995), a minuscule fraction of the entire Ghost Ranch assemblage.

On the other hand, evidence of large-scale herding should have a greater potential of being preserved in fossil assemblages than cannibalism, although extreme conditions, often catastrophic, would be required to kill enough individuals to be preserved in the fossil record as an indicator of herding behavior. Therefore, the fact that no evidence of herding is observed in PEFO assemblages does not necessarily falsify the behaviorial inferences made on the basis of the Ghost Ranch assemblage.

\section{CONCLUSIONS}

Early North American theropods lived in a semi-arid climate with strong seasonality of precipitation. They roamed the floodplains of meandering rivers al ongside aetosaurs, rauisuchians, ornithischians, and possibly phytosaurs and metoposaurs. They interacted with the other species in wetter areas of the floodplain, such as abandoned channels, where they probably gathered around water sources. Predation and mortality due to illness created time-averaged attritional bone assemblages that were incorporated in pal eosol s by episodic accumulation of sediments associated with floods and crevasse splays. Herbaceous and arborescent plants colonized the channel margins and levees, presumably related to the abundance of water (see Zuber, 1990). Distal floodplains werecovered by low vegetation; larger plants were excluded by reduced soil-moisture content. 
Paleosols and filled channels preserve a representative time-averaged sample of the fauna that inhabited the paleoenvironments at the time. Therefore, more can be learned about organisms, populations, ecosystems, evolutionary radiations, and extinctions in such settings than in catastrophic death assemblages, which represent localized and exceptional conditions of limited applicability (e.g., White et al., 1998).

The taphonomic setting of the Coelophysis quarry at Ghost Ranch is exceptional and unique. It results from a catastrophic event unlike anything recorded at other theropod localities in the American Southwest. F or this reason, extrapolation of behavior inferences, made on the basis of the Ghost Ranch setting, to other Coelophysis and early theropods must be done with caution.

\section{ACKNOWLEDGMENTS}

We thank the Petrified Forest Museum Association, F onds F CAR (Québec), and the Department of Geosciences at the University of Rhodelsland for their financial and technical support. We also thank O.D. Hermes for access to the XRF lab to conduct the geochemical analyses of paleosols.

Special thanks are extended to Alex Downs for allowing us to expose part of the Coelophysis quarry. The help of many volunteers (especially $H$. and J . Bachman, A. Britton, D. Chojnacki, B. Hawk, B. Kellet, M. Miller, and K. Taylor) during the excavation is greatly appreciated. We are grateful for the help and cooperation of the Petrified Forest National Park personnel during this research, communications with Russ Dubiel and Tim Demko, and constructive comments from two anonymous reviewers. We also wish to thank Gregory D. Hoke, Matthew M. J ones, Alisa S. Herrick, and J ack Rogers for discussion and assistance in the field. Part of this work was donein the context of F. Therrien's Master thesis at the URI Department of Geosciences.

\section{REFERENCES}

ALLEN, J .R.L., 1965, A review of the origin and characteristics of re cent alluvial sediments: Sedimentology, v. 5, p. 89-191.

AsLAN, A., and AUTIN, W.J ., 1998, Holoceneflood-plain soil formation in the southern lower Mississippi Valley: Implications for interpreting alluvial paleosols: Geological Society of America Bulletin, v. 110, p. 433-449.

AuberT, H., and PINTA, M., 1977, Trace Elements in Soils: Elsevier Scientific Publishing Company, New York, 395 p.

BAZARD, D.R., and BUTLER, R.F., 1991, Paleomagnetism of the Chinle and Kayenta Formations, New Mexico and Arizona: J ournal of Geophysical Research, v. 96, B6, p. 9847-9871.

BEHRENSMEYER, A.K., 1987, Miocene fluvial facies and vertebratetaphonomy in northern Pakistan: in Ethridge, F.G., Flores, R.M., and Harvey, M.D., eds., Recent development in fluvial sedimentology: Society of Economic Paleontologists and Mineralogists, Special Publication 39, p. 169-176.

Behrensmeyer, A.K., Western, D., and Dechant BoAz, D.E., 1979, New perspectives in vertebrate paleoecology from a recent bone assemblage: Paleobiology, v. 5, p. 12-21.

BILLINGSLEY, G.H., 1985a, General stratigraphy of the Petrified Forest National Park, Arizona: in Colbert,E.H., and J ohnson, R.R. eds., The Petrified F orest Through the Ages: Museum of Northern Arizona Press, Bulletin Series 54, p. 3-8.

BILLINGSLEY, G.H., 1985b, Geologic map of Petrified F orest National Park, Arizona: Report to Petrified Forest Museum Association, unpublished.
BIRKELAND, P.W., 1974, Pedology, Weathering, and Geomorphological Research: Oxford University Press, New York, 285 p.

BLAKEY, R.C., and GUBITOSA, R., 1983, Late Triassic paleogeography and depositional history of the Chinle Formation, southeastern Utah and northern Arizona: in Reynolds, M.W., and Dolly, E.D., eds., Mesozoic Paleogeography of West-Central United States: SEPM, Rocky Mountain Section, Denver, p. 57-76.

BLAKEY, R.C., and GUBITOSA, R., 1984, Controls of sandstone body geometry and architecture in the Chinle Formation (Upper Triassic), Colorado Plateau: Sedimentary Geology, v. 38, p. 51-86.

BLODGETT, R.H., 1988, Calcareous paleosols in the Triassic Dolores Formation, southwestern Colorado: in Reinhardt, J ., and Sigleo, W.R., Paleosols and Weathering Through Geologic Time: Principles and Applications: Geological Society of America Special Paper 216, p. 103-121.

Bown, T.M., and Kraus, M.J ., 1981a, Lower Eocene alluvial paleosols (Willwood F ormation, northwest Wyoming, U.S.A.) and their significance for paleoecology, paleodimatology, and basin analysis: Palaeogeography, Palaeoclimatology, Palaeoecology, v. 34, p. 1-30.

Bown, T.M., and Kraus, M.J ., 1981b, Vertebratefossil-bearing paleosol units (Willwood Formation, Lower Eocene, northwest Wyoming, U.S.A.): Implications for taphonomy, biostratigraphy, and assemblage analysis: Palaeogeography, Palaeodimatology, Palaeoecology, v. 34, p. 31-56.

Bown, T.M., and KRAUS, M.J ., 1987, Integration of channel and floodplain suites, I. Developmental sequence and lateral relations of alluvial paleosols: J ournal of Sedimentary Petrology, v. 57, p. 587601.

BRIDGE, J .S., 1985, Paleochannel patterns inferred from alluvial deposits: a critical evaluation: J ournal of Sedimentary Petrology, v. 55, p. 579-589.

Bullock, P., Fedoroff, N., J ongerius, A., Stoops, G., Tursina, T., and BABEL, U., 1985, Handbook for Soil Thin Section Description: Waine Research Publications, Wolverhampton, $152 \mathrm{p}$.

CANNON, W.A., 1911, The Root Habits of Desert Plants: The Carnegie Institution of Washington, Washington, D.C., $96 \mathrm{p}$.

CANT, D.J ., 1978, Development of a facies model for sandy braided river sedimentation: Comparison of the South Saskatchewan River and the Battery Point Formation: in Miall, A.D., ed., Fluvial Sedimentology: Canadian Society of Petroleum Geologists, Memoir 5, Calgary, p. 627-639.

CANT, D.J ., and WALKER, R.G., 1976, Development of a facies model for sandy braided-fluvial facies model for the Devonian Battery Point Sandstone, Quebec: Canadian J ournal of Earth Sciences, v. 13, p. 102-119.

CANT, D.J ., and WALKER, R.G., 1978, Fluvial processes and facies sequences in the sandy braided South Saskatchewan River, Canada: Sedimentology, v. 25, p. 625-648.

CLARK, J .M., and FASTOVSKY, D.E., 1986, Vertebratebiostratigraphy of the Glen Canyon Group in northern Arizona: in Padian, K., ed., The Beginning of the Age of the Dinosaurs: CambridgeUniversity Press, Cambridge, p. 285-301.

Colbert, E.H., 1947, The little dinosaurs of Ghost Ranch: Natural History, v. 59, p. 392-399, 427-428.

Colbert, E.H., 1964, The Triassic genera Podokesaurus and Coelophysis: American Museum Novitates, v. 2168, p. 1-12.

Colbert, E.H., 1989, The Triassic dinosaur Coel ophysis: Museum of Northern Arizona Bulletin 57, $160 \mathrm{p}$.

Colbert, E.H., 1995, The Little Dinosaurs of Ghost Ranch: Columbia University Press, New York, $250 \mathrm{p}$.

Collinson, J .D., 1978, Vertical sequence and sand body shape in alluvial sequences: in Miall, A.D., ed., Fluvial Sedimentology: Canadian Society of Petroleum Geologists, Memoir 5, Calgary, p. 577-587.

CovEY, D.S.G., 1993, Ontogenetic changes in hind limb proportions within the Ghost Ranch population of Coelophysis bauri: J ournal of Vertebrate Paleontology, Abstracts of Papers, Supplement to Number 3, v. 13, p. 31A.

Crown, P.H., and HoFFMAN, D.W., 1970, Relationship between water table levels and type of mottles in four Ontario gl eysols: Canadian J ournal of Soil Science, v. 50, p. 453-455.

Daniels, R.B., Gamble, E.E., and Nelson, L.A., 1971, Relations be- 
tween soil morphology and water-table levels on a dissected North Carolina coastal plain surface: Soil Science Society of America Proceedings, v. 35, p. 157-175.

DEMKO, T.M., 1995, Taphonomy of fossil plants in the Upper Triassic Chinle Formation: Unpublished Ph.D. Dissertation, University of Arizona, Tucson, $274 \mathrm{p}$.

Donahue, R.L., Shickluna, J .C., and Robertson, L.S., 1971, Soils, An Introduction to Soils and Plant Growth, third edition: PrenticeHall, Inc., Englewood Cliffs, 587 p.

Downs, A., and DAVIDGE, J ., 1997, A choristodere from the Ghost Ranch Coelophysis quarry: J ournal of Vertebrate Paleontology, Abstracts of Papers, Supplement to Number 3, v. 17, p. 43A-44A.

DUBIEL, R.F., 1989a, Sedimentol ogy and revised nomenclaturefor the upper part of the U pper Triassic Chinle Formation and the Lower J urassic Wingate Sandstone, northwestern New Mexico and northeastern Arizona: in Anderson, O.J ., Lucas, S.G., Love, D.W., and Cather, S.M., eds., Southeastern Colorado Plateau: New Mexico Geol ogical Society, 40th Field Conference Guidebook, p. 213223.

DUBIEL, R.F., 1989b, Depositional and dimatic setting of the Upper Triassic Chinle Formation, Colorado Plateau: in Lucas, S.G., and Hunt, A.P., eds., Dawn of the Age of the Dinosaurs in the American Southwest: New Mexico Museum of Natural History, Albuquerque, p. 171-187.

DUBIEL, R.F., 1989c, Depositional environments of the U pper Triassic Chinle Formation in the eastern San J uan Basin and vicinity, New Mexico: United States Geol ogical Survey Bulletin 1808-B, p. 1-22.

DUBIEL, R.F., 1994, Triassic deposystems, pal eogeography, and paleoclimate of the Western Interior: in Caputo, M.V., Peterson, J .A., and Franczyk, K.J ., eds., Mesozoic Systems of the Rocky Mountain region, USA: SEPM, Rocky Mountain Section, Denver, $p$. 133-168.

Dubiel, R.F., PARrish, J .T., PARRISH, J .M., and Good, S.G., 1991 The Pangaean monsoon-Evidence from the U pper Triassic Chinle Formation, Colorado Plateau: PALAIOS, v. 6, p. 347-370.

Dubiel, R.F., Demko, T.F., Hasiotis, S.T., Riggs, N.R., MAY, C.L., AsH, S.R., and LITWIN, R.J ., 1995, Triassic paleoecosystem reconstruction via fossil, ichnofossil, isotopic, and sedimentologic evidence integrated into a complete measured section, Chinle Formation, Petrified Forest National Park, AZ: Geological Society of America, Abstracts with Programs, v. 27, p. 9.

DUDAL, R., and EsWARAN, H., 1988, Distribution, properties and classification of Vertisols: in Wilding, L.P., and Puentes, R., eds., Vertisols: Their Distribution, Properties, Classification and Manage ment: Texas A\&M University Printing Center, Texas, p. 1-22.

ETHRIDGE, F.G., and SCHUMM, S.A., 1978, Reconstructing paleochannel morphologic and flow characteristics: Methodology, limitations, and assessment: in Miall, A.D., ed., Fluvial Sedimentology: Canadian Society of Petroleum Geol ogists, Memoir 5, p. 703-721.

FASTOVSKY, D.E., and MCSWEENEY, K., 1987, Paleosols spanning the Cretaceous-Paleogene transition, eastern Montana and western North Dakota: Geological Society of America Bulletin, v. 99, p. 6677.

FASTOVSKY, D.E., and MCSWEENEY, K., 1991, Paleocene paleosols of the petrified forests of Theodore Roosevelt National Park, North Dakota: A natural experiment in compound pedogenesis: PALAIOS, v. 6, p. 67-80.

FEAKES, C.R., and RETALLACK, G.J ., 1988, Recognition and chemical characterization of fossil soils developed on alluvium; A Late Ordovician example: in Reinhardt, J ., and Sigleo, W.R., eds., Paleosols and Weathering Through Geologic Time: Principles and Applications: Geological Society of America Special Paper 216, p. 3548.

GoudIE, A.S., 1973, Duricrusts in Tropical and Subtropical Landscapes: Oxford Clarendon Press, United Kingdom, 174 p.

GoudIE, A.S., 1983, Calcrete: in Goudie, A.S., and Pye, K., eds., Chemical Sediments and Geomorphology-Precipitates and $\mathrm{Re}$ sidua in the Near-Surface Environment: Academic Press, Inc., Orlando, p. 93-131.

HASIOTIS, S.T., and DuBIEL, R.F., 1993, Continental trace fossils of the Upper Triassic Chinle Formation, Petrified Forest National Park, Arizona: in Lucas, S.G., and Morales, M., eds., The Nonmar- ine Triassic: New Mexico Museum of Natural History \& Science Bulletin no. 3, p. 175-178.

HECKERT, A.B., 1997, Litho- and biostratigraphy of the Lower Chinle Group, east-central Arizona and west-central New Mexico, with a description of a new theropod (Dinosauria: Theropoda) from the Bluewater Creek Formation: Unpublished M.S. Thesis, University of New Mexico, Albuquerque, $278 \mathrm{p}$.

HeRrick, A.S., J ONES, M.M., TherRien, F., Hoke, G.D., and FASTOVSKY, D.E., 1999, Late Triassic depositional systems and paleoenvironmental changes in Petrified Forest National Park, Arizona: Geol ogical Society of America, Abstracts with Programs, v. 31, no. 2, p. A23.

HuNT, A.P., 1998, Preliminary results of the Dawn of the Dinosaurs project at Petrified Forest National Park, Arizona: in Santucci, V.L., and McClelland, L., eds., National Park Service Paleontological Research: National Park Service (Technical Report NPS/ NRGRD/GRDTR-98/01), Denver, p. 135-137.

HUNT, A.P., and LUCAS, S.G., 1993, Stratigraphy and vertebrate paleontology of the Chinle Group (Upper Triassic), Chama Basin, north-central New Mexico: Vertebrate Paleontology in New Mexico, N ew Mexico Museum of Natural History \& Science, Bulletin 2, p. 61-69.

Hunt, A.P., SANTucCI, V.L., and Newell, A.J ., 1995, Late Triassic vertebrate taphonomy at Petrified Forest National Park: in Santucci, V.L., and McClelland, L., eds., National Park Service Paleontological Research: National Park Service (Technical Report NPS/NRPO/NRTR-95/16), Denver, p. 97-101.

Hunt, A.P., Olson, T.J ., Huber, P., Shipman, T., Bricheff, P., and Frost, J .E., 1996, A new theropod locality at the Petrified Forest National Park with a review of LateTriassic dinosaur localities in the park: Proceedings of the F ossils of Arizona Symposium, v. 4, p. 55-61.

Hunt, A.P., Lucas, S.G., HeCKert, A.B., Sullivan, R.M., and LockLEY, M.G., 1998, LateTriassic dinosaurs from the Western United States: GEOBIOS, v. 31, p. 511-531.

J ACKSON, R.G. II, 1978, Preliminary evaluation of lithofacies models for meandering alluvial streams: in Miall, A.D., ed., Fluvial Sedimentology: Canadian Society of Petroleum Geologists, Memoir 5, p. 543-576.

J OHNS, M.E, 1988, Architectural element analysis and depositional history of the upper Petrified Forest Member of the Chinle Formation, Petrified Forest National Park, Arizona: Unpublished M.S. Thesis, Northern Arizona University, Flagstaff, 163 p.

KabatA-Pendias, A., and Pendias, H., 1984, Trace Elements in Soils and Plants: CRC Press, Inc., Boca Raton, 315 p.

KOSTER, E.H., 1987, Vertebrate taphonomy applied to the analysis of ancient fluvial systems: in Ethridge, F.G., Flores, R.M., and Harvey, M.D., eds., Recent Development in Fluvial Sedimentology: Society of Economic Paleontologists and Mineralogists, Special Publication 39, p. 159-168.

KraUS, M.J ., and Bown, T.M., 1986, Paleosols and time resolution in alluvial stratigraphy: in Wright, V.P., ed., Paleosols-Their Recognition and Interpretation: Princeton University Press, N ew J ersey, p. 180-207.

KraUS, M.J ., and MIDDLETON, L.T., 1987, Dissected pal eotopography and base level changes in a Triassic fluvial sequence: Geology, v. 15, p. 18-21.

LoNG, R.A., 1985, A guide to the fossil vertebrates of Petrified Forest National Park: Report to the Petrified Forest Museum Association, unpublished.

LoNG, R.A., and MuRRY, P.A., 1995, Late Triassic (Carnian and Norian) tetrapods from the southwestern United States: New Mexico Museum of Natural History and Science Bulletin, 4, $254 \mathrm{p}$.

LONG, R.A., and PADIAN, K., 1986, Vertebrate biostratigraphy of the Late Triassic Chinle Formation, Petrified Forest National Park, Arizona: Preliminary results: in Padian, K., ed., The Beginning of the Age of the Dinosaurs: Cambridge University Press, Cambridge, p. 161-169.

Long, R.A., Houk, R., and HENDERSON, D., 1988, Dawn of the Dinosaurs: The Triassic in Petrified Forest: Petrified Forest Museum Association, Petrified Forest National Park, Arizona, $96 \mathrm{p}$.

LUCAS, S.G., 1993, The Chinle Group: Revised stratigraphy and biochronology of U pper Triassic nonmarine strata in the western 
United States: in Morales, M., ed., Aspects of Mesozoic Geology and Paleontology of the Colorado Plateau: Museum of Northern Arizona Bulletin, 59, p. 27-50.

MCBRIDE, E.F., 1974, Significance of col or in red, green, purple, olive, brown, and gray beds of Difunta Group, northeastern Mexico: J ournal of Sedimentary Petrology, v. 44, p. 760-773.

MCCARTHY, P.J ., MARTINI, I.P., and LECKIE, D.A., 1998, Use of micromorphology for paleoenvironmental interpretation of complex alluvial palaeosols: An example from the Mill Creek Formation (Albian), southwestern Alberta, Canada: Palaeogeography, Palaeoclimatology, Palaeoecology, v. 143, p. 87-110.

MunSELl COLOR, 1992, Munsell Soil Color Charts (revised edition 1992): Newburgh, New York, MacBeth Division of theK ollmorgen Corporation.

MURRY, P.A., 1990, Stratigraphy of the U pper Triassic Petrified Forest Member (ChinleF ormation) in Petrified Forest National Park, Arizona, USA: J ournal of Geology, v. 98, p. 780-789.

MURRY, P.A., and LoNG, R.A., 1989, Geology and paleontology of the Chinle Formation, Petrified Forest National Park and vicinity, Arizona, and a discussion of vertebrate fossils of the southwestern Upper Triassic: in Lucas, S.G., and Hunt, A.P., eds., Dawn of the Age of the Dinosaurs in the American Southwest: New Mexico Museum of Natural History, p. 29-64.

PADIAN, K., 1986, On the type material of Coelophysis Cope (Saurischia: Theropoda) and a new specimen from the Petrified Forest of Arizona (Late Triassic: Chinle Formation): in Padian, K., ed., The Beginning of the Age of the Dinosaurs: Cambridge University Press, Cambridge, p. 45-60.

PADIAN, K., 1990, The ornithischian form genus Revud tosaurus from the Petrified Forest of Arizona (Late Triassic: Chinle Formation): J ournal of Vertebrate Paleontology, v. 10, p. 268-269.

PARRISH, J .M., 1989, Vertebrate paleoecology of the Chinle Formation (Late Triassic) of the southwestern United States: Palaeogeography, Palaeoclimatology, Palaeoecol ogy, v. 72, p. 227-247.

PARRISH, J .M., 1991, A new specimen of an early crocodylomorph (cf. Sphenosuchus sp.) from the U pper Triassic Chinle Formation of Petrified Forest National Park, Arizona:J ournal of VertebratePaleontology, v. 11, p. 198-212.

PARRISH, J .M., 1993, Distribution and taxonomic composition of fossil vertebrate accumulations in the Upper Triassic Chinle Formation, Petrified Forest National Park: in Lucas, S.G., and Morales, M., eds., The Nonmarine Triassic: New Mexico Museum of Natural History \& Science Bulletin No. 3, p. 393-396.

Reeves, C.C., J R., 1976, Caliche: Origin, Classification, Morphology, and U ses: Estacado Books, Lubbock, Texas, $233 \mathrm{p}$.

RETALLACK, G.J ., 1983, Late Eocene and Oligocene paleosols from Badlands National Park, South Dakota: Geological Society of America, Special Paper 193, $82 \mathrm{p}$.

RetALLACK, G.J ., 1990, Soils of the Past: An Introduction to Paleope dology: Unwin Hyman, Boston, $520 \mathrm{p}$.

Schumm, S.A., 1968, River adjustment to altered hydrologic regimen-Murrumbidgee River and paleochannels, Australia: United States Geological Survey Professional Paper 598, 65 p.
SCHWARTZ, H.L., and GILLETTE, D.D., 1994, Geology and taphonomy of the Codophysis quarry, Upper Triassic Chinle Formation, Ghost Ranch, New Mexico:J ournal of Paleontology, v. 68, p. 11181130.

Sternberg, C.M., 1970, Comments on dinosaurian preservation in the Cretaceous of Alberta and Wyoming: National Museum of Canada, Publications in Paleontology, v. 4, p. 1-9.

SteWART, J .H., PoOle, F.G., and WILSON, R.F., 1972, Stratigraphy and origin of the Chinle Formation and related Upper Triassic strata in the Colorado Plateau region: United States Geological Survey Professional Paper 690, $336 \mathrm{p}$.

Sullivan, R.M., LUCAS, S.G., HECKERT, A., and Hunt, A.P., 1996 The type locality of Codophysis, a Late Triassic dinosaur from north-central New Mexico (USA): PalaeontologischeZeitschrift, v. 70, p. 245-255.

TherRIEN, F., 1999, Theropod mortality in the Late Triassic Chinle Formation: a comparison of Petrified Forest National Park (Arizona) and Ghost Ranch (New Mexico): Unpublished M.S. Thesis, University of Rhode Island, $258 \mathrm{p}$.

Therrien, F., HeRrick, A.S., J ONES, M.M., Hoke, G.D., and FASTOVSKY, D.E., 1999, Paleoenvironmental changes in the Chinle Formation as seen in vertebrate localities of the Petrified F orest $\mathrm{Na}$ tional Park, Arizona: Geological Society of America, Abstracts with Programs, v. 31, no. 2, p. A72.

Trinh, T.A., TRINH, T.A., GoldSTEIN, B.S, and Demko, T.M., 1996, Sedimentology, stratigraphy, and paleontology of the Chinle Formation, Ghost Ranch, New Mexico: Paleoenvironmental interpre tation: Geological Society of America, Abstracts with Programs, v. 28, no. 5, p. 118-119.

VAN DER Voo, R., MAUK, F.J ., and FrenCH, R.B., 1976, Permian-Triassic continental configurations and the origin of the Gulf of Mexico: Geology, v. 4, p. 177-180.

VEPRASKAS, M.J ., 1992, Redoximorphic features for identifying aquic conditions: North Carolina Agriculture Research Service, Technical Bulletin 301, 33 p.

WhiTE, P.D., FASTOVSKY, D.E., and SheehAN, P.M., 1998, Taphonomy and suggested structure of the dinosaurian assemblage of the Hell Creek Formation (Maastrichtian), eastern Montana and western North Dakota: PALAIOS, v. 13, p. 41-51.

WILDING, L.P., and TESSIER, D., 1988, Genesis of Vertisols: Shrinkswell phenomena: in Wilding, L.P., and Puentes, R., eds., Vertisols: Their Distribution, Properties, Classification and Management: Texas A\&M University Printing Center, Texas, p. 55-81.

WITTE, W.K., and KENT, D.V., 1989, A middle Carnian to early Norian ( $225 \mathrm{Ma}$ ) paleopole from sediments of the Newark Basin, Pennsylvania: Geological Society of America Bulletin, v. 101, p. 11181126.

ZUBER, J.D., 1990, Geochemistry and sedimentology of paleosols in the Upper Petrified Forest Member, Chinle Formation, Petrified Forest National Park, Arizona: Unpublished M.S. Thesis, Northern Arizona University, Flagstaff, $152 \mathrm{p}$.

ACCEPTED FEBRUARY 8, 2000 